\title{
Paleocene orthophragminids from the Lakadong Limestone, Mawmluh Quarry section, Meghalaya (Shillong, NE India): implications for the regional geology and paleobiogeography
}

\author{
Ercan Özcan ${ }^{1}$, Johannes Pignatti ${ }^{2}$, Christer Pereira ${ }^{3}$, Ali Osman Yücel ${ }^{1}$, Katica Drobne ${ }^{4}$, \\ Filippo Barattolo ${ }^{5}$, and Pratul Kumar Saraswati ${ }^{3}$ \\ ${ }^{1}$ Department of Geological Engineering, Faculty of Mines, İstanbul \\ Technical University (ITU), Maslak, 34469 Istanbul, Turkey \\ ${ }^{2}$ Dipartimento di Scienze della Terra, Università degli Studi di Roma "La Sapienza", Rome, Italy \\ ${ }^{3}$ Department of Earth Sciences, Indian Institute of Technology, Bombay, Powai, Mumbai 400 076, India \\ ${ }^{4}$ Palaeontological Institute I. Rakovec ZRC SAZU, Novi trg 2, 1000 Ljubljana, Slovenia \\ ${ }^{5}$ Dipartimento di Scienze della Terra, dell'Ambiente e delle Risorse \\ Largo San Marcellino, 10, 80138 Naples, Italy \\ Correspondence: Ercan Özcan (ozcanerc@itu.edu.tr)
}

Received: 29 November 2017 - Revised: 16 March 2018 - Accepted: 24 March 2018 - Published: 18 April 2018

\begin{abstract}
The late Paleocene orthophragminids, hitherto poorly known from the Himalayan foreland basins, are studied from the Lakadong Limestone in Meghalaya, northeastern India, in order to establish a systematic, biostratigraphic, and paleobiogeographical framework for them in the eastern Tethys. In the Mawmluh Quarry section (MQS) on the Shillong Plateau, to the southeast of Tibet, orthophragminids are associated with typical Paleocene orbitoidiform taxa endemic to the Indian subcontinent, i.e., Lakadongia Matsumaru \& Jauhri (= Setia Ferràndez-Cañadell) and Orbitosiphon Rao, and various species of alveolinids, miscellaneids, and rotaliids, characterizing the Shallow Benthic Zones (SBZ) 3 and 4. The orthophragminids belong to two lineages of the genus Orbitoclypeus Silvestri: $O$. schopeni (Checchia-Rispoli) and $O$. multiplicatus (Gümbel), both well known from the peri-Mediterranean region and Europe (western Tethys). The latter species is identified here for the first time from the eastern Tethys. Previous records of the genus Discocyclina Gümbel from the Lakadong Limestone actually correspond to misidentified Orbitoclypeus; this implies that the late Paleocene orthophragminid assemblages from Meghalaya and eastern Tethys were less diverse than in the western Tethys. The lineage of Orbitoclypeus schopeni in the lower part of the Lakadong Limestone (SBZ 3) is identified as O. schopeni cf. ramaraoi based on the morphometry of a few specimens, whereas in the upper part (SBZ 4) it corresponds to a transitional development stage between $O$. schopeni ramaraoi and $O$. schopeni neumannae (with average $D_{\text {mean }}$ values ranging between 192 and $199 \mu \mathrm{m}$ ). The embryon diameters of $O$. multiplicatus, recorded only in SBZ 4, range between 300 and $319 \mu \mathrm{m}$ on average, corresponding to transitional development stages of $O$. multiplicatus haymanaensis and $O$. multiplicatus multiplicatus. Our data, along with a review of previous Paleocene and Eocene records from India and Pakistan, suggest that Orbitoclypeus is the only orthophragminid in the Paleocene of the eastern Tethys, whereas Discocyclina first appears in early Eocene times, being mainly represented by endemic taxa confined to the Indian subcontinent. Facies change in the MQS from a marine to continental setting within SBZ 4 corresponds to the oldest record from the Indian plate in the Paleogene, which may be linked to the flexural uplift of the passive margin of the Indian plate, marking the onset of the collision of the Indian and Eurasian plates.
\end{abstract}




\section{Introduction}

Orthophragminids are a group of larger benthic foraminifera (LBF) that inhabited the upper Paleocene-Eocene circumtropical continental shelves and platforms around the globe (Less, 1987). Despite their widespread distribution and a reasonably high number of evolutionary lineages established from the peri-Mediterranean region (western Tethys), a Tethyan-scale biostratigraphic model and a paleobiogeographical scheme have not yet been established because of lack of data from the eastern Tethys (Wan, 1991; Wan et al., 2010; Zhang et al., 2013; Özcan et al., 2014; BouDagherFadel and Price, 2017). In the peri-Mediterranean region and Europe, both Discocyclina Gümbel and Orbitoclypeus Silvestri appear simultaneously in the Thanetian and orthophragminids become more diverse with the first appearance of Nemkovella Less and Asterocyclina Gümbel after the Paleocene-Eocene boundary (Less et al., 2007; Özcan et al., 2014). The main records of Paleocene orthophragminids from the eastern Tethys come from the Lakadong Limestone in Meghalaya, where a detailed taxonomic study of the group has until now not been available. The occurrence of two orthophragminid genera, Discocyclina Gümbel and Orbitoclypeus Silvestri, has been reported in previous works from this unit from random thin sections; Discocyclina was not identified at the species level, whereas the only orbitoclypeid recorded was Orbitoclypeus ramaraoi (O. schopeni ramaraoi) (Jauhri, 1994, 1998; Matsumaru and Sarma, 2010). In India, south of the Tethyan domain, Paleocene orthophragminids have been recorded in some detail only from the Cauvery Basin (Pondicherry area) in SE India (Samanta, 1967). Here, orthophragminids are represented only by Orbitoclypeus schopeni ramaraoi (Discocyclina ramaraoi of Samanta, 1967), the most primitive member of the O. schopeni lineage of Less et al. (2007). Other records of Paleocene orthophragminids from the eastern Tethys, e.g., the Andaman Islands (Koley and Wanjarwadkar, 2013), and the southern margin of the Asian plate (Zhongba area, Tibet) (BouDagher-Fadel et al., 2015), are based on poorly preserved or indeterminable uncentered sections.

Here, our aim is to fill the gap in information on the eastern Tethyan Paleocene orthophragminids based on the new data from the Lakadong Limestone in Meghalaya. Matrixfree orthophragminid tests were extracted from marly and silty levels to make equatorial sections in order to investigate the embryon and equatorial chambers and obtain the morphometric parameters necessary for subspecies identification. In addition to equatorial sections, axial and subaxial sections of megalospheric forms are illustrated in order to facilitate generic and specific recognition in rock thin sections. The distribution of Tethyan Paleocene orthophragminids is reinterpreted in light of the new data.

\section{Geological setting and stratigraphy}

The Shillong Plateau in NE India consists of a Precambrian basement and is covered by Cretaceous and Cenozoic sedimentary deposits in the south, which form a raised topography in the foreland of the Himalayas (Fig. 1) (Biswas et al., 2007; Najman et al., 2016). The southern fringes of the Shillong Plateau, commonly referred to as the southern Shillong Plateau, form the Khasi-Jaintia Hills. The Paleogene succession exposed in the southern Shillong Plateau is represented by the Paleocene fluvio-deltaic Langpar and Therria formations, consisting of fine calcareous shales with occasional limestone bands and a thick sandstone succession, and the overlying Sylhet Limestone Group subdivided into several units: the Lakadong, Umlatdoh, and Prang formations intercalated with two mainly sandstone units (Lakadong Sandstone and Narpuh Sandstone) (Wilson and Metre, 1953). These units are interpreted to record three marine transgressions in the late Paleocene, the early Eocene, and the middle Eocene and are overlain by the upper Eocene Kopili Formation (Jauhri, 1994, 1998). The Lakadong Formation consists of the Lakadong Limestone Member, comprising shallow marine algal-foraminiferal facies, extensively developed in the Khasi and Jaintia Hills, and the Lakadong Sandstone Member, a sandstone-shale unit with coal seams (Jauhri, 1994; Garg and Khowaja-Ateequzzaman, 2000; Srivastava and Prasad, 2015). In the Lakadong Formation, LBF occur only in the Lakadong Limestone Member and this unit has been extensively studied for red algae and LBF (Jauhri, 1994, 1998; Jauhri and Agarwal, 2001; Matsumaru and Jauhri, 2003; Jauhri et al., 2006; Gogoi et al., 2009; Tewari et al., 2010; Matsumaru and Sarma, 2010). The age of the unit has been reported either as late Paleocene or to range from the late Paleocene to the early Eocene at different outcrops in Meghalaya based on LBF, most commonly alveolinids and miscellaneids. The unit contains diverse assemblages, including miscellaneids, alveolinids, rotaliids, orthophragminids, textulariids, miliolids, encrusting foraminifera, coralline and dasycladalean algae, gastropods, echinoids, bivalves, and scarce coral fragments.

\section{Materials and methods}

The Lakadong Limestone was logged in the Mawmluh Quarry section (MQS), located near the Mawmluh cement factory, ca. $2.5 \mathrm{~km}$ southwest of Cherrapunji on the southern Shillong Plateau (base of the section: $25^{\circ} 15^{\prime} 26.72^{\prime \prime} \mathrm{N}, 91^{\circ} 42^{\prime} 47.01^{\prime \prime} \mathrm{E}$; top of the section: $25^{\circ} 15^{\prime} 23.39^{\prime \prime} \mathrm{N}, 91^{\circ} 42^{\prime} 52.03^{\prime \prime} \mathrm{E}$ ) (Fig. 1). Here, the outcropping succession is about $36 \mathrm{~m}$ thick and consists of dolomite, dolomitic limestone, limestone with intervening levels of shale, siltstone, and sandstone (Fig. 2). Although the bottom of the section is largely obliterated by alluvium, nearby ex- 


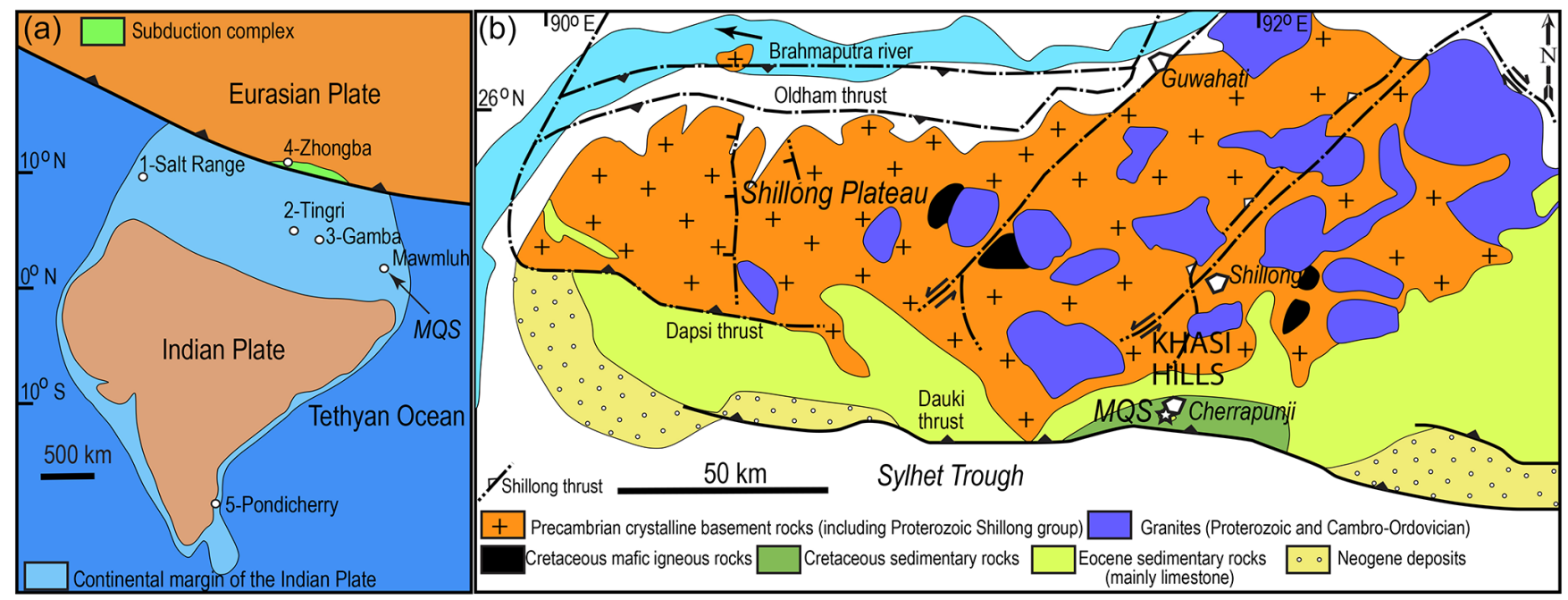

Figure 1. (a) Tentative location of the Mawmluh Quarry section (MQS) on Thanetian (ca. 59-56 Ma) paleogeographic cartoon after Hu et al. (2016). Locations of key upper Paleocene shallow-marine sections with LBF in eastern Tethys (1-4) and SE India (5) are shown. (b) Geological map of the Shillong Plateau (simplified from Yin et al., 2010). Pondicherry is the type locality of Orbitoclypeus schopeni ramaraoi, the most primitive subspecies of the Orbitoclypeus schopeni lineage (Samanta, 1967; Less, 1987).

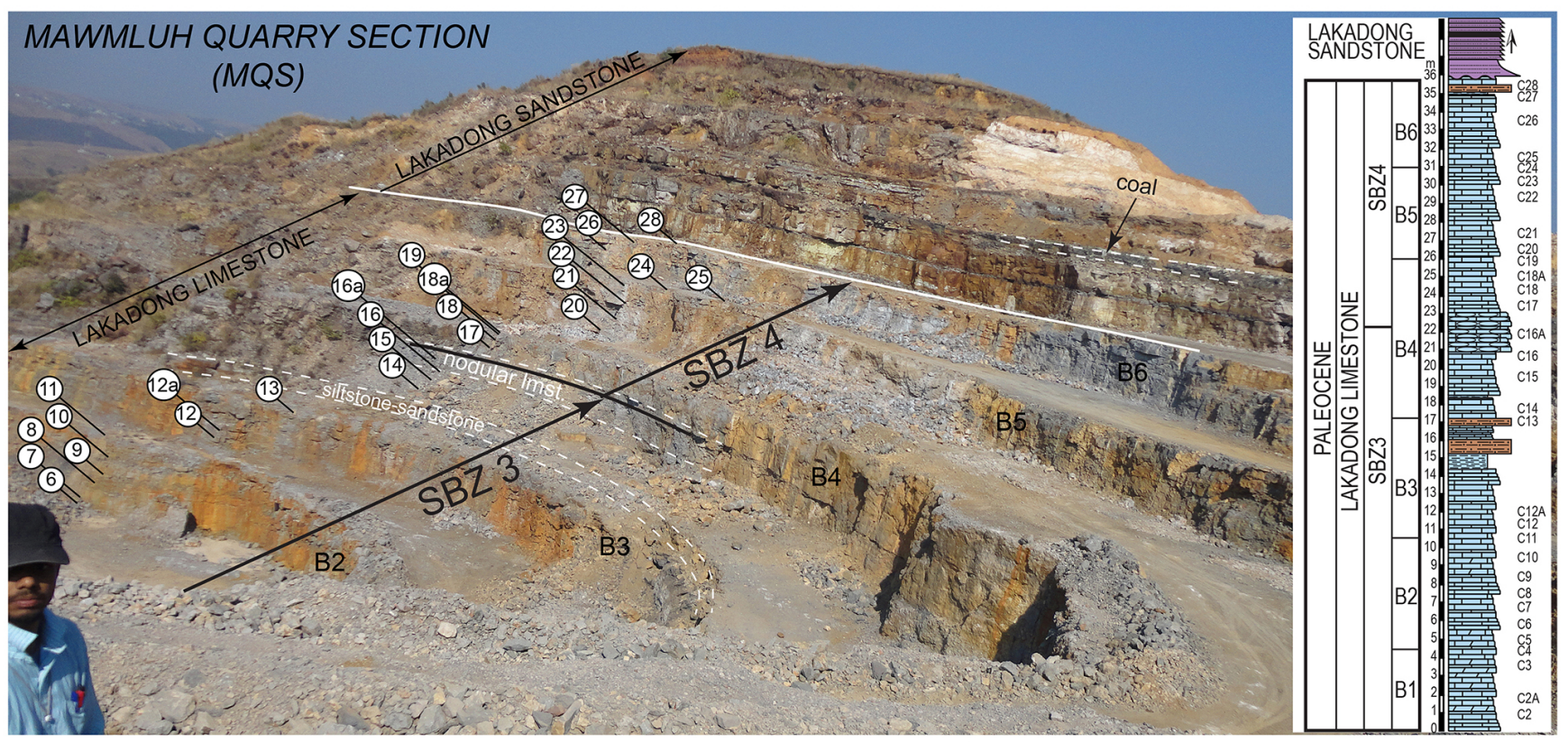

Figure 2. The Lakadong Limestone in MQS, position of the samples and simplified stratigraphic column of the quarry. The position of the boundary between SBZ 3 and 4 is tentative. The position of the lower samples (C1-5) from the first bench (B1), are not seen here. B: benches in the limestone.

posures of the unit reveal that in the MQS the exposed lower part of the Lakadong Limestone is very close to the contact with the underlying Therria Formation.

A total of 31 samples from the indurated limestonedolomitic limestone, and some loose orthophragminid specimens from levels C5, 9, 24, 25, 27, and 28, were collected (Fig. 2). Specimens extracted from the shale, marl, and lime- stone beds were studied for their external and internal features in equatorial and axial sections. Oriented equatorial sections of megalospheric and partly microspherical specimens (A and B forms, respectively) were prepared because the most important taxonomic and evolutionary parameters are observed in this part of the test (Less, 1987; FerràndezCañadell, 1998). Biometric measurements and counts were 


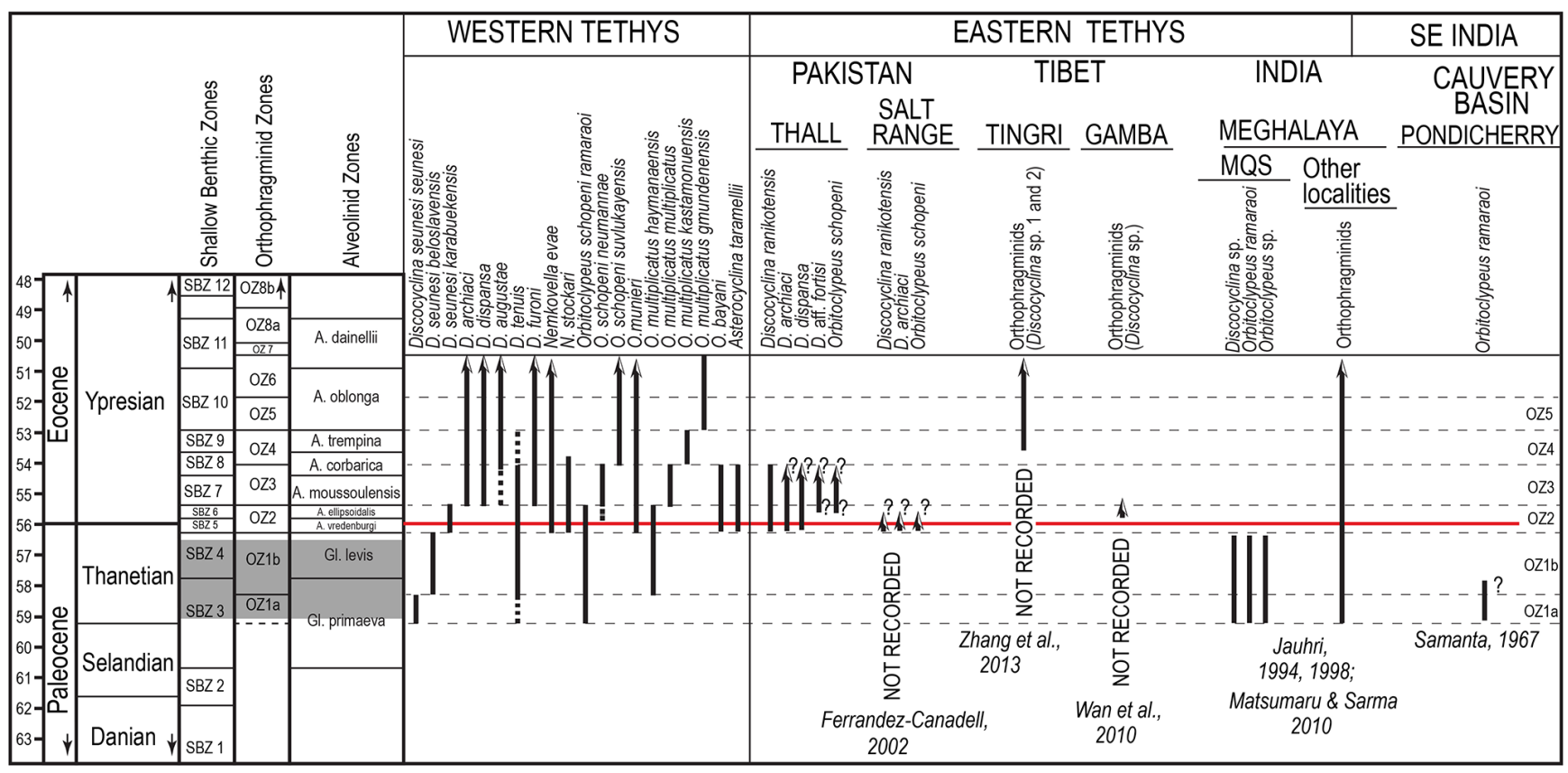

Figure 3. Records of orthophragminids in the Paleocene and across the Paleocene-Eocene boundary in Tethys and SE India. The Shallow Benthic Zones (SBZ) are after Serra-Kiel et al. (1998), modified by Drobne et al. (2014) and Papazzoni et al. (2017) with respect to the Paleocene-Eocene boundary. The orthophragminid zones (OZ) are from Less et al. (2007) and their boundaries with respect to SBZ zones are after Papazzoni et al. (2017). The alveolinid zones are after Hottinger (1960) and Drobne (1977).

carried out on equatorial sections of the megalospheric specimens (Less, 1987, 1998). Finally, axial and subaxial sections of megalospheric forms were prepared and photographed in order to facilitate specific recognition in rock thin sections.

\section{A historical background for Tethyan Paleocene orthophragminids}

The late Paleocene phylogeny of Tethyan orthophragminids was reconstructed from localities in Europe and the periMediterranean region, a part of the western Tethyan bioprovince (Schlumberger, 1903; Douvillé, 1922; Neumann, 1958; Samuel et al., 1972; Less, 1987; Zakrevskaya, 2007; Less et al., 2007; Özcan et al., 2014), whereas a systematic study from the eastern Tethys is lacking. In the western Tethys, Paleocene orthophragminids are represented by several species (lineages) of Discocyclina Gümbel and Orbitoclypeus Silvestri, enabling us to characterize the Thanetian by two orthophragminid zones (OZ), 1a, b and a part of OZ 2 crossing the Paleocene-Eocene boundary (Less et al., 2007). These zones correspond to the Tethyan Shallow Benthic Zones (SBZ) 3, 4, and in part 5 (sensu Papazzoni et al., 2017) (Fig. 3).

The Paleocene orthophragminids from eastern Tethys, however, are little known either because of the absence of the group in some Paleocene key outcrops in Tibet and Pakistan or because of the difficulty in obtaining free specimens for detailed taxonomic study as in the case of MQS. The Paleocene deposits in Pakistan (e.g., the Lockhart Limestone in the Salt Range) and the Tethyan Himalayas (e.g., the Zhepure Shan and Zongpu formations in Tingri and Gamba regions in Tibet, China) did not yield orthophragminids but only orbitoidiform foraminifers such as Orbitosiphon Rao and Lakadongia Matsumaru and Jauhri (=Setia FerràndezCañadell, see below), in addition to other LBF (Nagappa, 1959; Hu et al., 1976; Wan, 1991; Ferràndez-Cañadell, 2002; Wan et al., 2010; Zhang et al., 2013) (Fig. 3). The earliest orthophragminids in the Salt Range are known after the Paleocene-Eocene boundary in the Alveolina vredenburgi Zone (SBZ 5) (Ferràndez-Cañadell, 2002). From the Tethyan Himalayas of Tibet they have been first recorded in the mid-late Ypresian (SBZ 9/10) (Zhang et al., 2013); their first occurrence from the Asian plate (Zhongba area) in Tibet has been recorded much earlier, in the late Thanetian (SBZ 4) (BouDagher-Fadel et al., 2015). In the eastern Tethys, to the southeast of Tingri and Gamba, Paleocene orthophragminids, associated with Glomalveolina primaeva Reichel, Orbitosiphon punjabensis (Davies), Lakadongia tibetica (Douvillé), miscellaneids, and rotaliids, have been reported only from the Lakadong Limestone in the Shillong Plateau in the Meghalaya region (e.g., Mawmluh Quarry section) (Dutta and Jain, 1980; Jauhri, 1994, 1998; Jauhri et al., 2006; Matsumaru and Jauhri, 2003; Matsumaru and Sarma, 2010; Tewari et al., 2010). These orthophragminids 
were previously mainly described from axial and tangential sections in rock thin sections and were assigned to either Discocyclina or Orbitoclypeus with contrasting specieslevel identifications. Jauhri (1998) first mentioned the occurrence of Orbitoclypeus ramaraoi $(O$. schopeni ramaraoi of Less, 1987) in the Lakadong Limestone from the Um Sohryngkew River section near the Therria village in the southern Shillong Plateau, without any illustration and discussion. The orthophragminids from the same section, however, were assigned to Discocyclina by Jauhri et al. (2006) without any reference to Orbitoclypeus previously reported by Jauhri (1998). Matsumaru and Sarma (2010) recorded Orbitoclypeus ramaraoi in oblique sections, although these authors also incorrectly assigned some sections of Orbitoclypeus to Orbitosiphon tibetica.

Further southward along the Indian subcontinent, Paleocene orthophragminids have been recorded only from the Cauvery Basin (Pondicherry area) in SE India (Samanta, 1967). Here, the orthophragminids are represented only by Orbitoclypeus schopeni ramaraoi, the most primitive member of the $O$. schopeni lineage. The associated LBF assemblages of this area are poorly characterized (Govindan, 2013) and the identification of Ranikothalia by Samanta (1980) should be revised: his figured specimens do not show a marginal chord and appear to be rotaliids (Daviesina), not nummulitids. The assemblages do not permit the assignment of a precise SBZ age to these shallow-marine deposits consisting of strongly burrowed, several-meter-thick argillaceous carbonates. Records of late Paleocene orthophragminids from the Andaman Islands are similarly based on loosely dated assemblages yielding Ranikothalia (Koley and Wanjarwadkar, 2013).

\section{The facies, LBF, and associated fauna and flora in MQS}

The Lakadong Limestone contains a diverse association of benthic foraminifera of such groups as the miscellaneids, alveolinids, orthophragminids, rotaliids, miliolids, and textulariids, accompanied by dasycladalean and coralline algae, rare corals, bryozoans, echinoids, bivalves, and gastropods (Figs. 4-6). The foraminifera are represented by the following genera: Orbitoclypeus Silvestri, Lakadongia Matsumaru and Jauhri (=Setia Ferràndez-Cañadell, see below for detailed explanation); Orbitosiphon Rao; Ornatanomalina Haque; Lockhartia Davies; Miscellanea Pfender; Carterella Sirel; Ranikothalia Caudri; Elazigella Sirel; Rotalia Lamarck; Aberisphaera Wan; Glomalveolina Hottinger; Rotorbinella Bandy; Idalina Munier-Chalmas and Schlumberger; Valvulina d'Orbigny; Orduella Sirel; Globotextularia Eimer and Fickert; Mardinella Meriç and Çoruh (=Azzarolina Vicedo and Serra-Kiel); Periloculina MunierChalmas and Schlumberger; Cincoriola Haque; Kathina Smout; and Pachyrotalia Hottinger (Fig. 5). The unit con- sists of wackestones-packstones dominated by LBF and coralline-dasycladacean algae, which are characteristic of inner- to middle and middle to outer shelf environments (Nebelsick et al., 2005) (Figs. 4 and 5). Most of the section, between samples 1 and 20, yielding alveolinids, miscellaneids, and rotaliids, was deposited in an inner to middle shelf setting, whereas the upper part (samples 21-28), with orthophragminids and less abundant rotaliids and miscellaneids, was deposited in a middle to outer shelf depositional setting. This suggests a general deepening upsection. Among the alveolinids, the occurrence of Glomalveolina cf. sireli and also G. primaeva in the lower and middle part of the section is significant for the assignment of SBZ 3. The first appearance of Glomalveolina cf. levis in sample $\mathrm{C} 17$ is used to place the boundary between SBZ 3 and SBZ 4, which corresponds tentatively to $22 \mathrm{~m}$ in the section.

Orthophragminids are scarce in the interval from the first sample of the section up to sample C20, where Distichoplax biserialis becomes abundant. The occurrence of Lakadongia, abundant in the middle part of the section below sample C21, declines sharply upward in the section, with a single record in the last sample (C28). The orthophragminids are subdivided into two lineages of the genus Orbitoclypeus Silvestri, the lineages of $O$. schopeni (Checchia-Rispoli) and O. multiplicatus (Gümbel). In the lower part of the section (SBZ 3 and lower part of SBZ 4), the specimens belonging to Orbitoclypeus schopeni are identified as O. schopeni ramaraoi based on morphometry (with an average $D_{\text {mean }}$ value of $188.3 \mu \mathrm{m}$ for sample $\mathrm{C} 21$ ), whereas those in the upper part (SBZ 4) represent a transitional development stage between $O$. schopeni ramaraoi and $O$. schopeni neumannae (with average $D_{\text {mean }}$ values ranging between 192.9 and $198.3 \mu \mathrm{m}$ ). The embryon diameter of $O$. multiplicatus, recorded only in SBZ 4, ranges between 300.0 and $318.3 \mu \mathrm{m}$ on average, corresponding to the transitional development stages of $O . \mathrm{mul}$ tiplicatus haymanaensis and O. multiplicatus multiplicatus.

Algae are essentially represented by red and green algae, among which Distichoplax biserialis (Dietrich) Pia is the most common in MQS (Fig. 6). Fragments of other corallinaceans also occur through the section, while crustose thalli of Lithoporella sp. are only recorded from sample C15 up to sample C28. Polystrata alba (Pfender) Denizot is occasionally found. Among green algae, dasycladales are predominant. Thyrsoporellids are rather common throughout the section and include Thyrsoporella turgidipora Radoičić, Belzungia pfenderae Radoičić, and Özgen-Erdem, Belzungia cf. terquemi Morellet and Morellet, Dissocladella gracilis Radoičić and Furcoporella diplopora Pia, the latter species being found only in the middle and upper part of the section. Among neomerids, Indopolia cf. satyavanti Pia and $\mathrm{Cy}$ mopolia aff. sirmiensis Radoičić are recorded. Acetabulariaceans are characterized by Clypeina rotella Wang, Acicularia tavnae Radoičić, and Orioporella malaviae Pia. Apart from Ovulites morelleti Elliott commonly occurring in the 


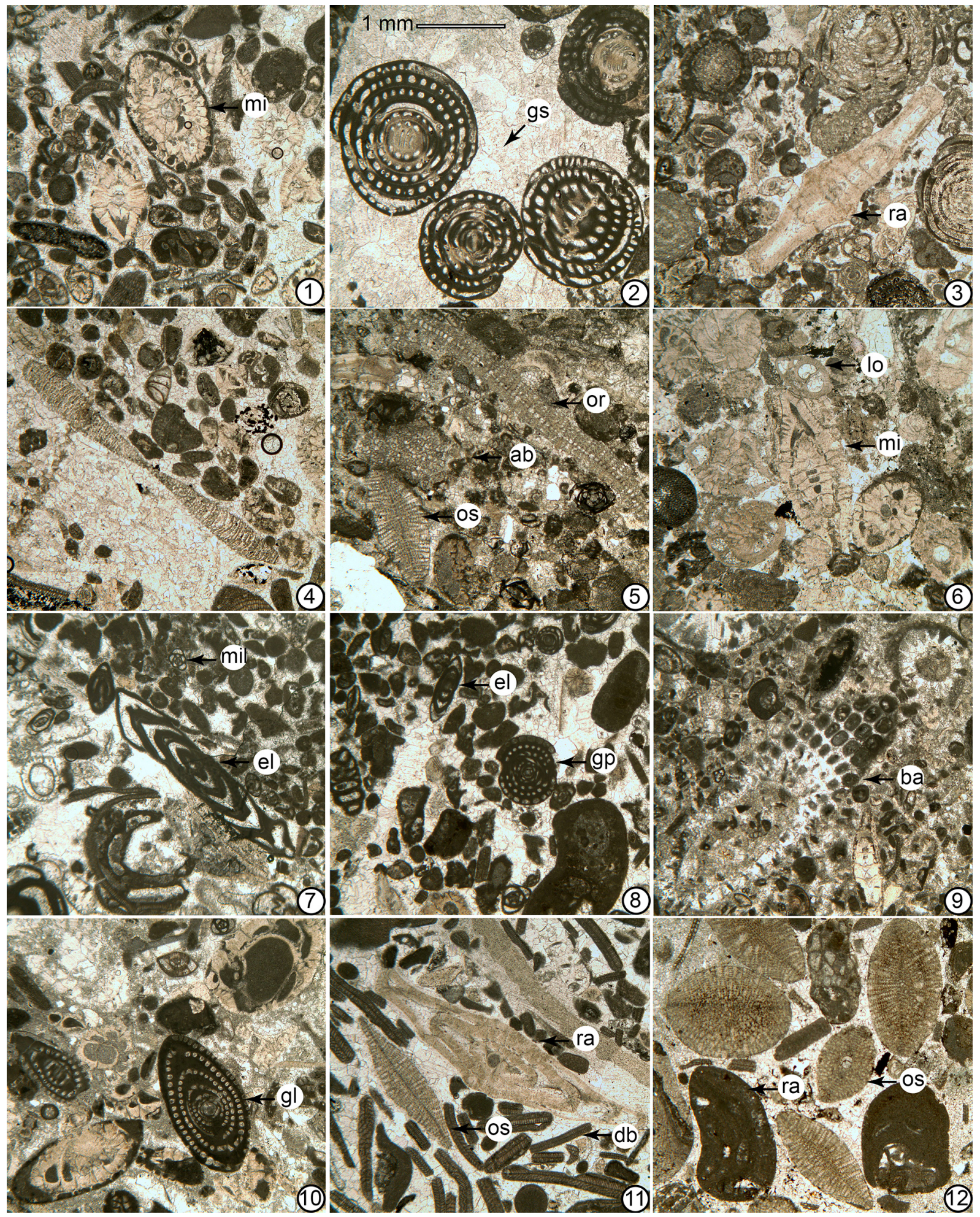

Figure 4. Thin-section photomicrographs of foraminiferal and algal assemblages in the Lakadong Limestone. 1: miscellaneid foraminiferred algal wackestone-packstone with miscellaneids (mi); 2-3, 7-8: Glomalveolina-dasycladalean algae-miliolid wackestone-packstone with Glomalveolina cf. sireli (gs), Glomalveolina primaeva (gp), Ranikothalia sp. (ra), Elazigella altineri (el), and miliolids (mil); 4, 6, 9-10: miscellaneid foraminifera-Glomalveolina wackestone-packstone with Lockhartia sp. (lo), miscellaneids (mi), Bakalovaella sp. (ba), Glomalveolina levis (gl); 5: Aberisphaera-red algal wackestone-packstone with Aberisphaera sp. (ab), Orbitoclypeus schopeni (os) and Orbitosiphon pubjabensis (or); 11-12: orthophragminid-red algal- Distichoplax packstone-grainstone with Ranikothalia sp. (ra), Orbitoclypeus schopeni (os), Distichoplax biserialis (db) and red algae (ra). 1: sample C2; 2: sample C6; 3: sample C8; 4: sample C10; 5: sample C12; 6: sample C12A; 7: sample C15; 8: sample C16; 9: sample C17; 10: sample C19; 11: sample C22; 12: sample C23. 


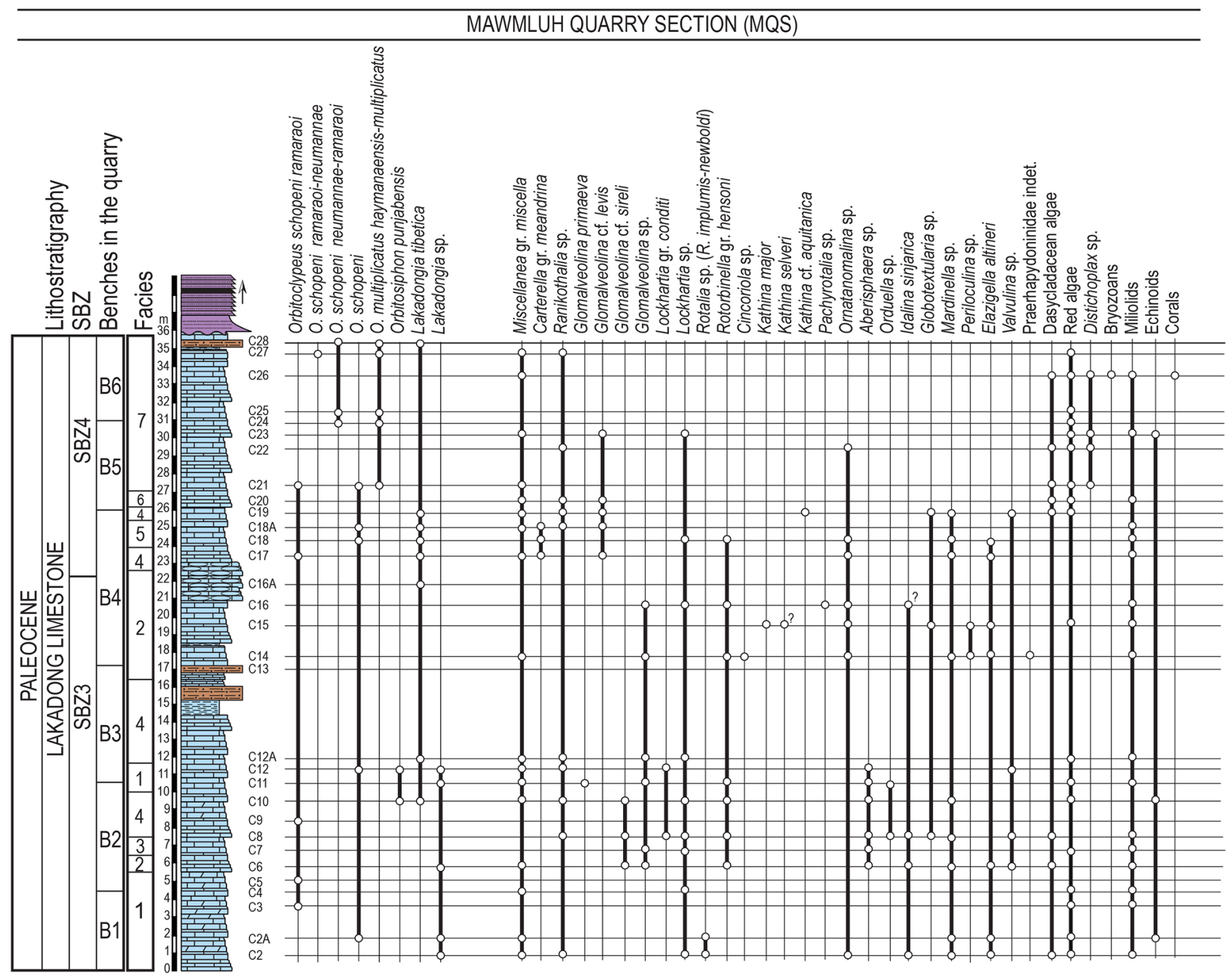

Figure 5. Lithostratigraphic column of the Lakadong Limestone in MQS, facies, and distribution of LBF and other fossil groups with inferred SBZ zones by Serra-Kiel et al. (1998). Facies explanation: 1: miscellaneids-red algal wackestone-packstone, 2: Glomalveolinadasycladalean algae-miliolid wackestone-packstone, 3: Aberisphaera-red algal wackestone-packstone, 4: miscellaneids-Glomalveolina wackestone-packstone, 5: Lakadongia-Glomalveolina wackestone-packstone, 6: dasycladalean algal wackestone, 7; orthophragminid-red algal- Distichoplax packstone-grainstone.

lower-middle part of the section, other green algae bryopsidales are found in the upper part and consist of disclike segments of Halimeda cf. tuna Lamouroux and a large specimen tentatively identified as Arabicodium sp. Dasycladaleans inhabit shallow warm waters (Valet, 1979) in particular thyrsoporellids are interpreted to prefer mid-ramp environments (Barattolo, 2002). Many taxa recognized in the MQS are characteristic for European and North African Thanetian-Ypresian successions. Indopolia satyavanti, Orioporella malaviae, and Clypeina rotella are recognized here for the first time from the NE Indian area. The latter species, recorded only at its type locality in Tibet, is poorly known.

\section{Systematic paleontology}

We follow the taxonomic concept adopted for western Tethyan Paleocene orthophragminids by Less (1987) and Less et al. (2007). The details of morphometric discrimination of subspecies in orthophragminids are explained in Less and Kovács (2008). Eight test measurements (in micrometers) and counts and some qualitative data (e.g., types of embryon configurations and adauxiliary chamberlets) were used to characterize the taxa (Fig. 7 and Table 1). These measurements and counts are $P$ and $D$, outer diameter of the protoconch and deuteroconch perpendicular to their common axis; $A$, number of adauxiliary chamberlets; $H$ and $W$, height and width of the adauxiliary chamberlets; $n_{0.5}$, number of annuli 


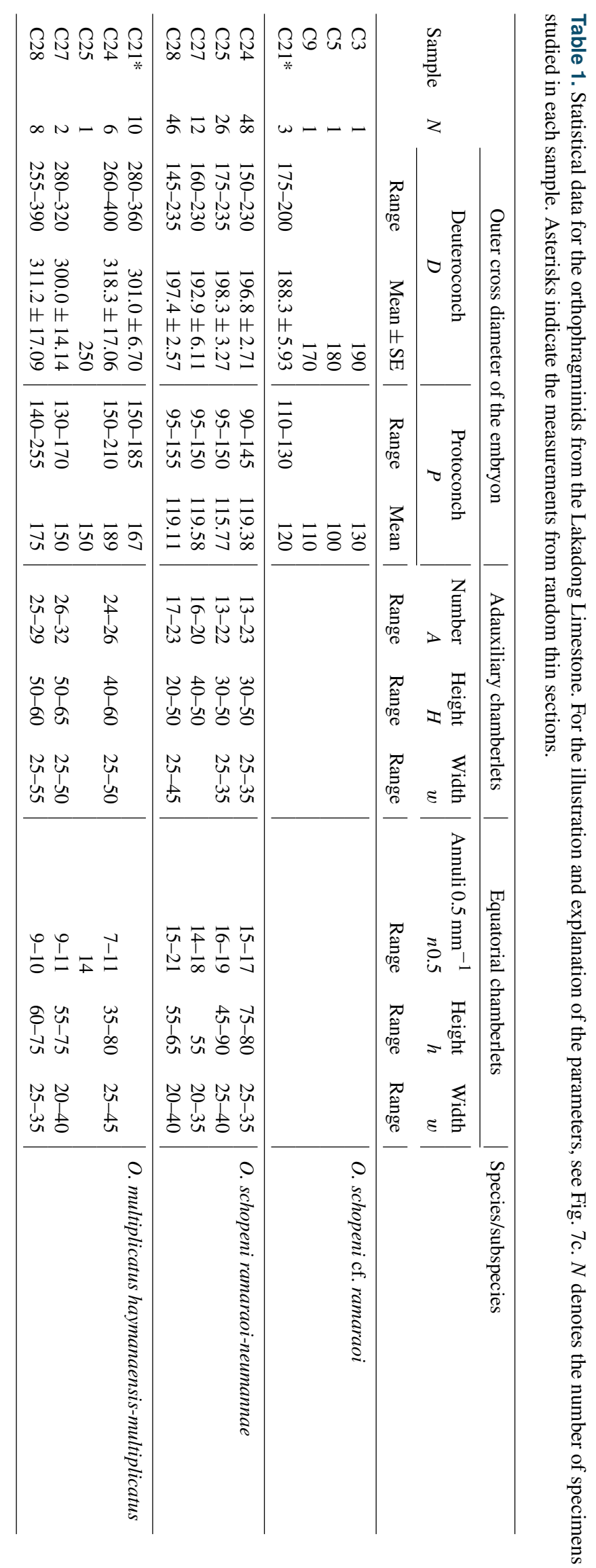




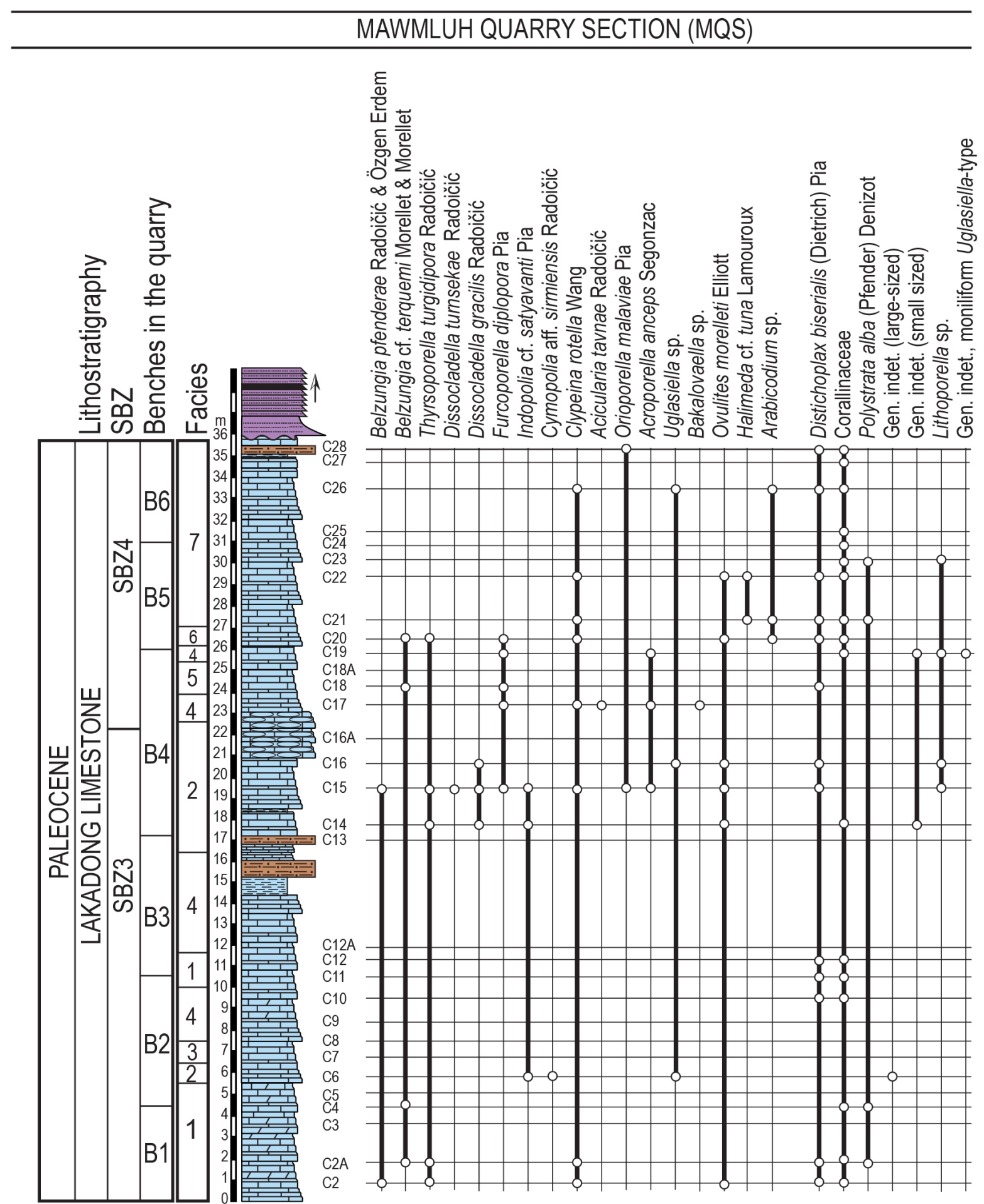

Figure 6. Distribution of algae in MQS. See Fig. 5 for facies explanation.

within a $0.5 \mathrm{~mm}$ distance measured from the deuteroconch along the axis of the embryon; and $h$ and $w$, height and width of the equatorial chamberlets around the peripheral part of the equatorial layer.
Order Foraminiferida Eichwald

Family Orbitoclypeidae Brönnimann

Genus Orbitoclypeus Silvestri 


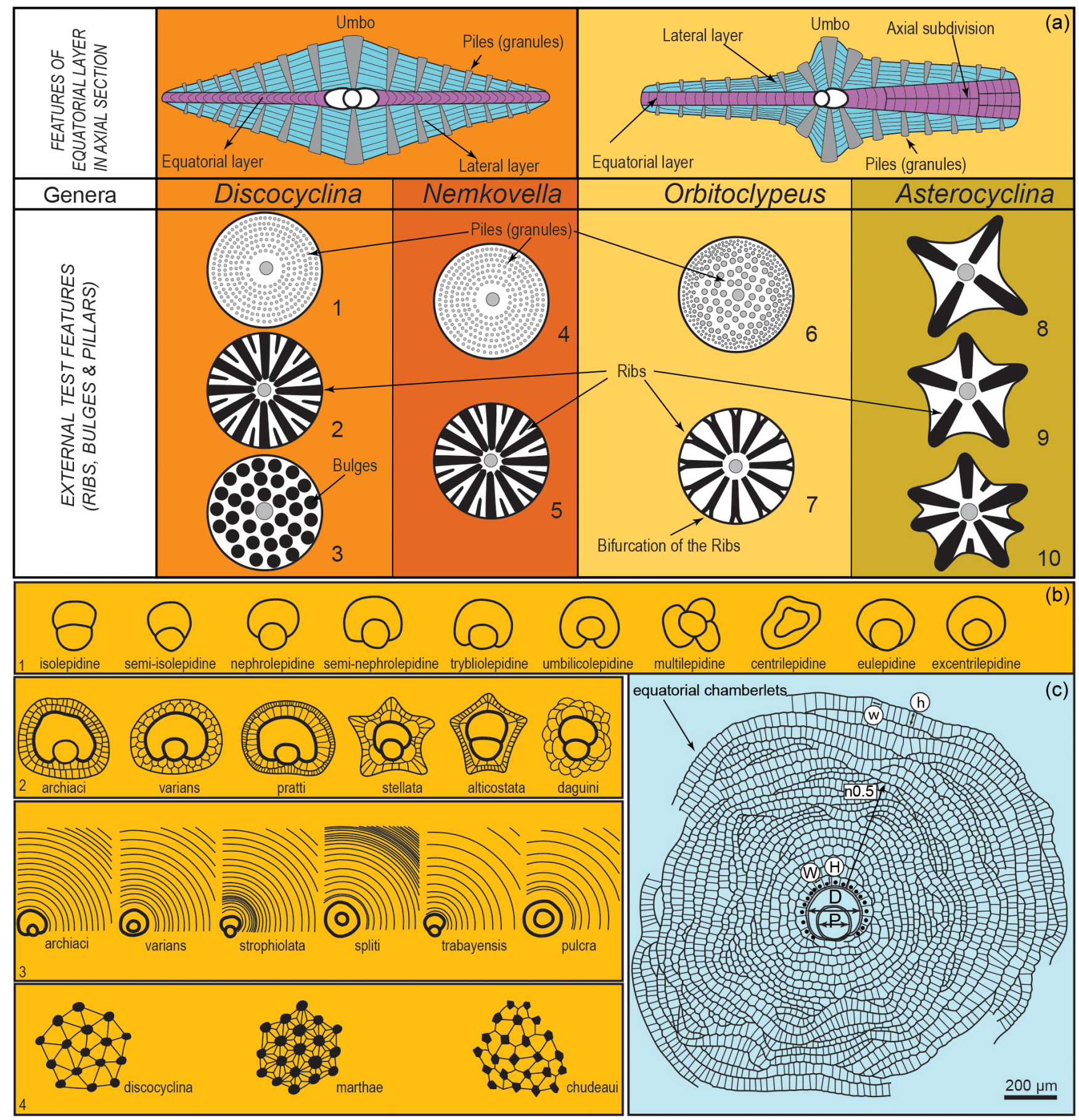

Figure 7. (a) General test features in Tethyan orthophragminid genera (after Less, 1987; Ferràndez-Cañadell, 1997; Özcan et al., 2016b). (b) Qualitative parameters: 1: types of embryon configurations; 2: types of adauxiliary chamberlets, 3: different growth patterns of the equatorial annuli; 4: types of granules and lateral chamberlets on the test surface; and (c) parameters used in the morphometric description of orthophragminids as illustrated in Orbitoclypeus schopeni ramaraoi-neumannae from MQS.

Orbitoclypeus schopeni (Checchia-Rispoli, 1908)

Diagnosis: Orbitoclypeus schopeni is an unribbed species with a "marthae" type rosette, a small to relatively large, eu, tryblio-, and excentrilepidine embryon; narrow or medium wide, low or medium high "varians" type adauxiliary chamberlets; and also narrow or medium wide equatorial chamberlets arranged into circular or slightly undulated annuli usually with varians type growth pattern. The distal margins of the 


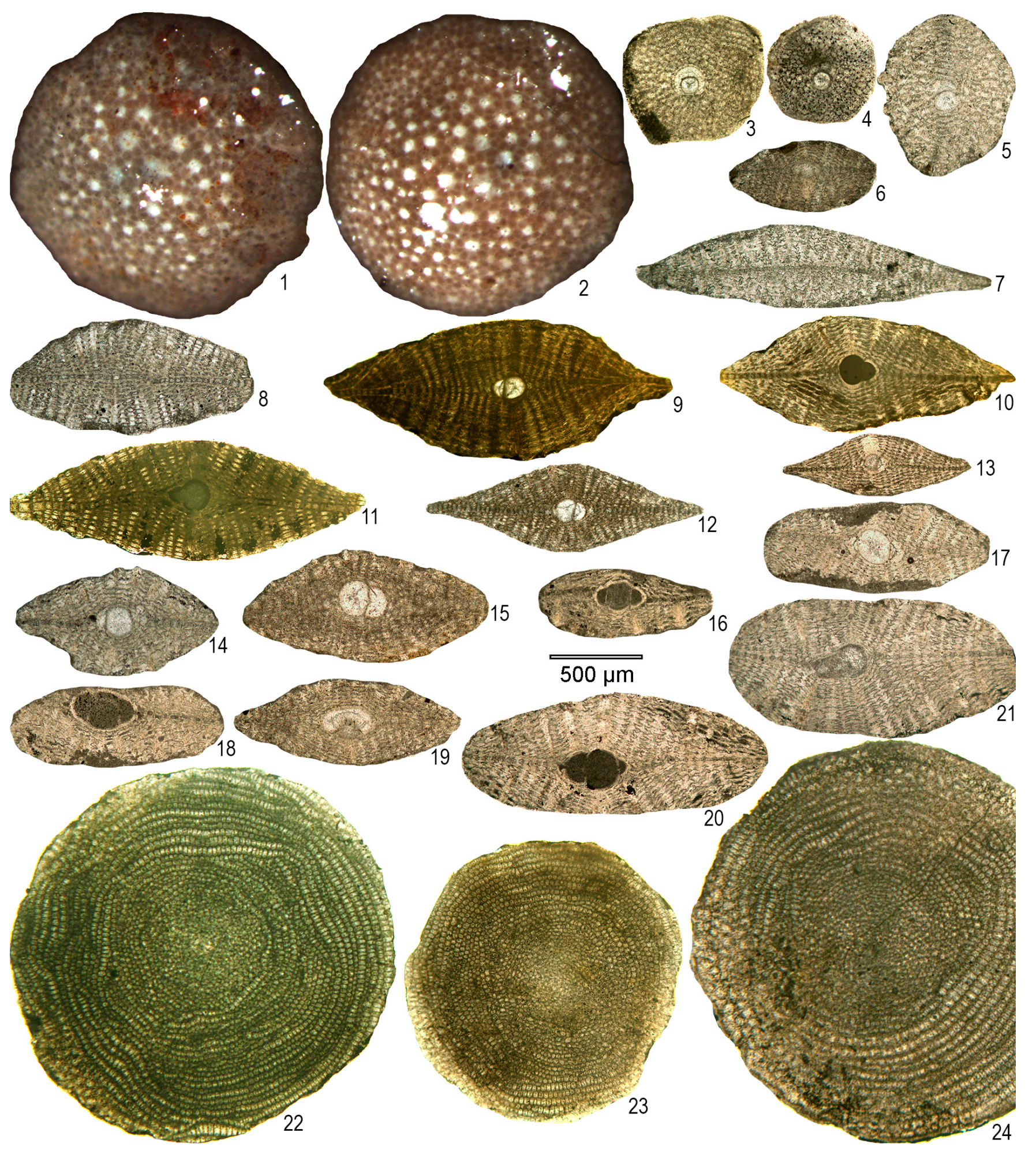

Figure 8. 1-2, 9-13, 22-24: Orbitoclypeus schopeni ramaraoi-neumannae; 1-2: external views, 9-13: axial sections, 22-24: equatorial sections of B forms. 1: C28-42, 2: C28-43, 9: C24-43, 10: C25-30, 11: C27-30, 12: C22-19, 13: C21, 22: C24-3, 23: C24-39, 24: C2438. 3-8: Orbitoclypeus schopeni cf. ramaraoi; 3-4: equatorial sections, 3: C5-1, 4: C9-1. 5: slightly oblique equatorial section, C3-1. 6: axial section, C18, 7-8: off-center axial sections, 7: C2A, a microspherical form, 8: C12. 14-21: Orbitoclypeus multiplicatus haymanaensismultiplicatus; axial to slightly off-center axial sections, 14: C21, 15: C21, 16: C21, 17: C21, 18: C21,19: C21, 20: C28, 21 : C28. 

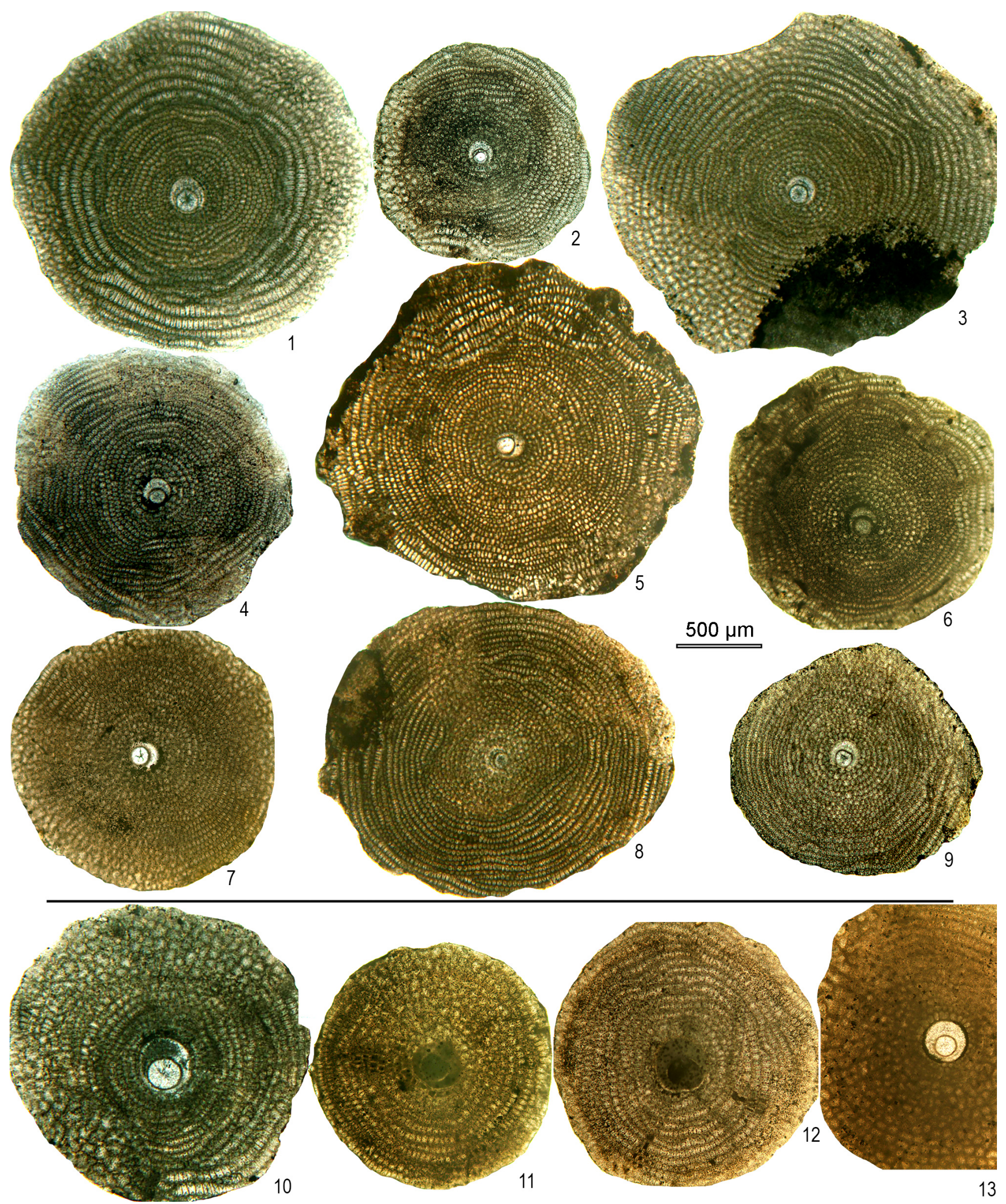

Figure 9. 1-9: Orbitoclypeus schopeni ramaraoi-neumannae; equatorial sections, 1: C24-7, 2: C24-4, 3: C24-20, 4: C24-12, 5: C25-9, 6: C24-20, 7: C24-36, 8: C25-1, 9: C25-26. 10-13: Orbitoclypeus multiplicatus haymanaensis-multiplicatus; equatorial sections, 10: C24-6, 11: C24-41, 12: C24-45, 13: C27-31. 


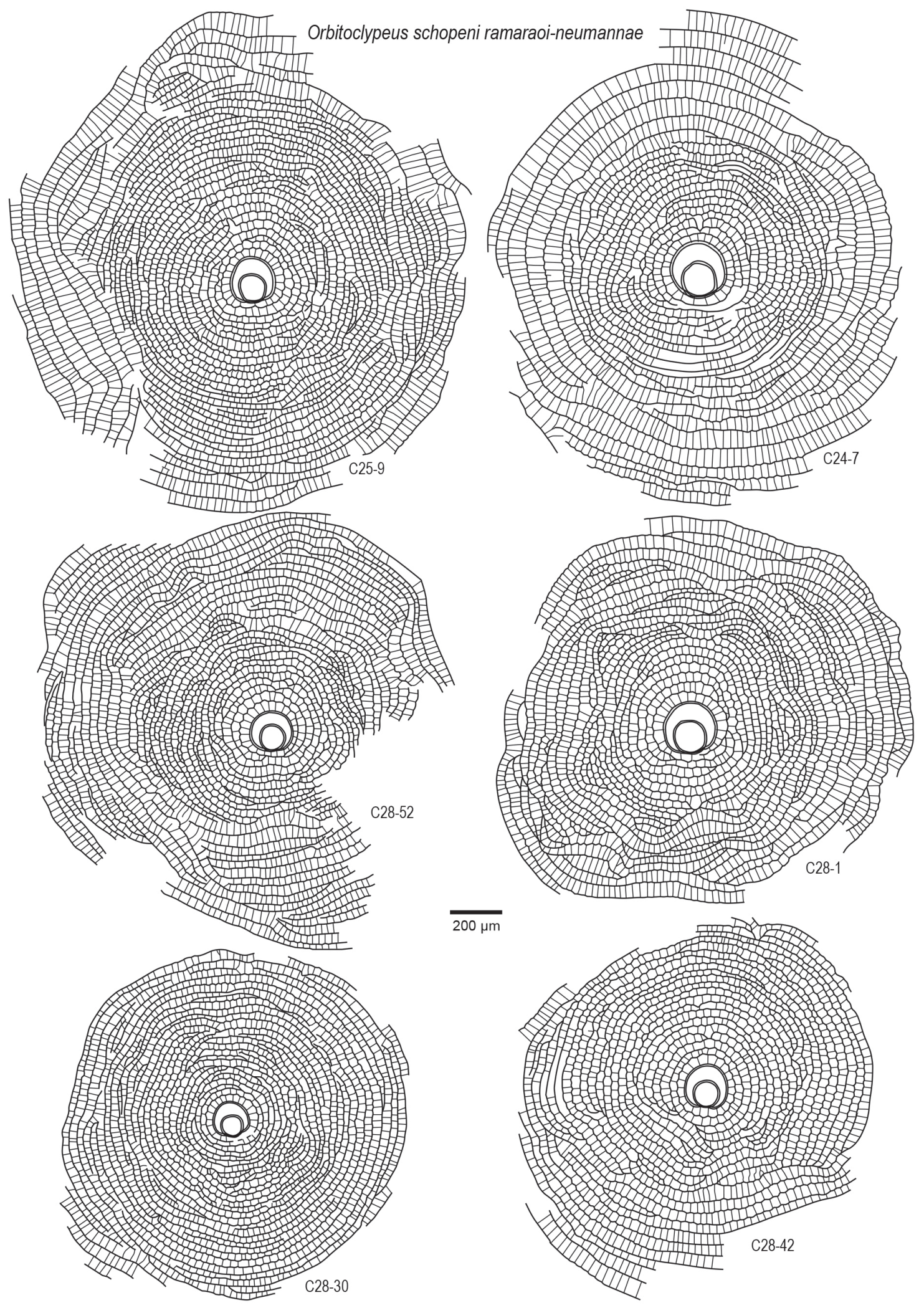

Figure 10. Embryon and equatorial chambers in Orbitoclypeus schopeni ramaraoi-neumannae. Note that the embryon is of eulepidine type, some equatorial chambers are incomplete and slightly wavy in pattern, and the distal sides of the chamberlets are arcuate to wedge shaped. 


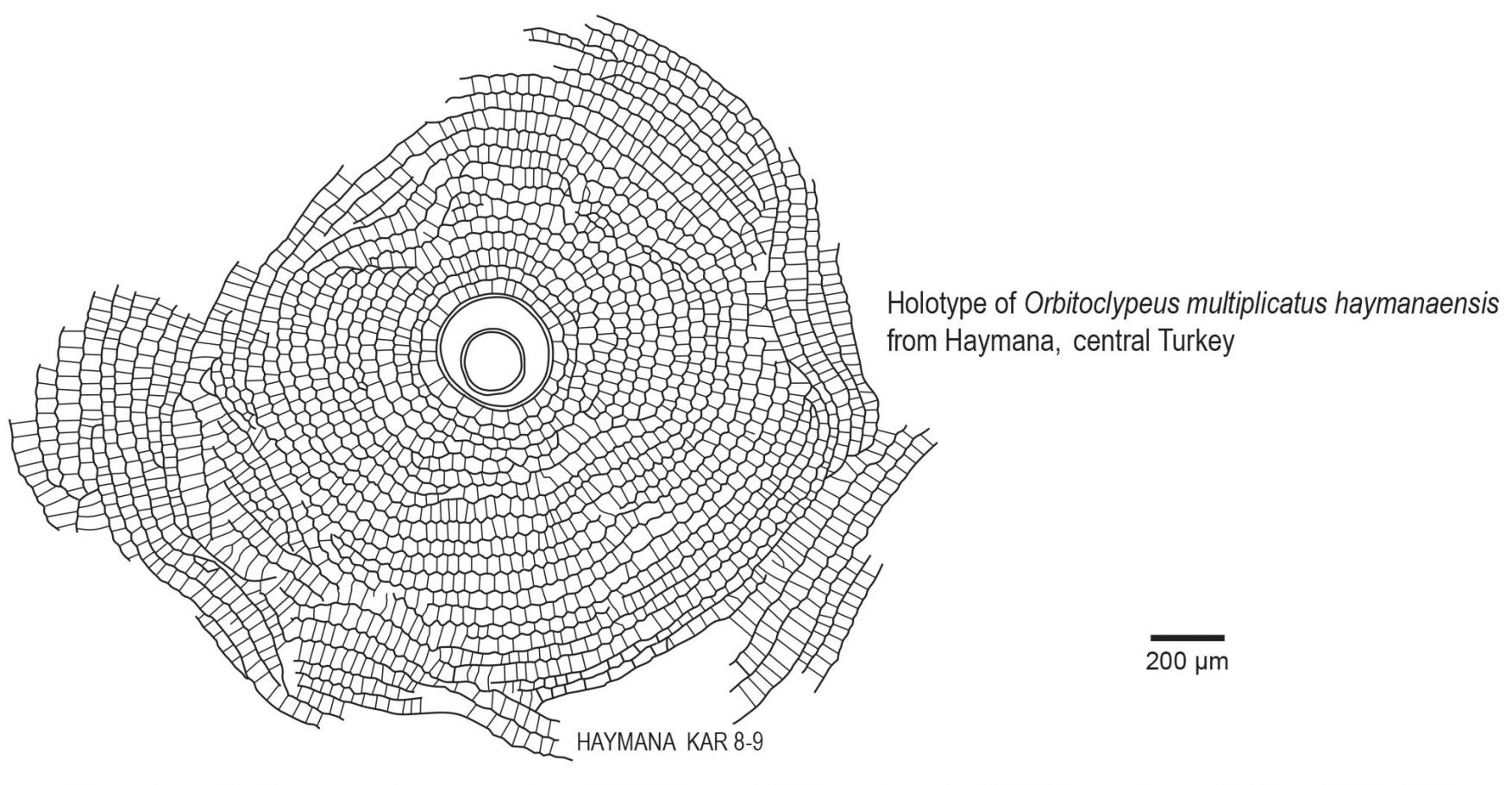

Orbitoclypeus muliplicatus haymanaensis-multiplicatus

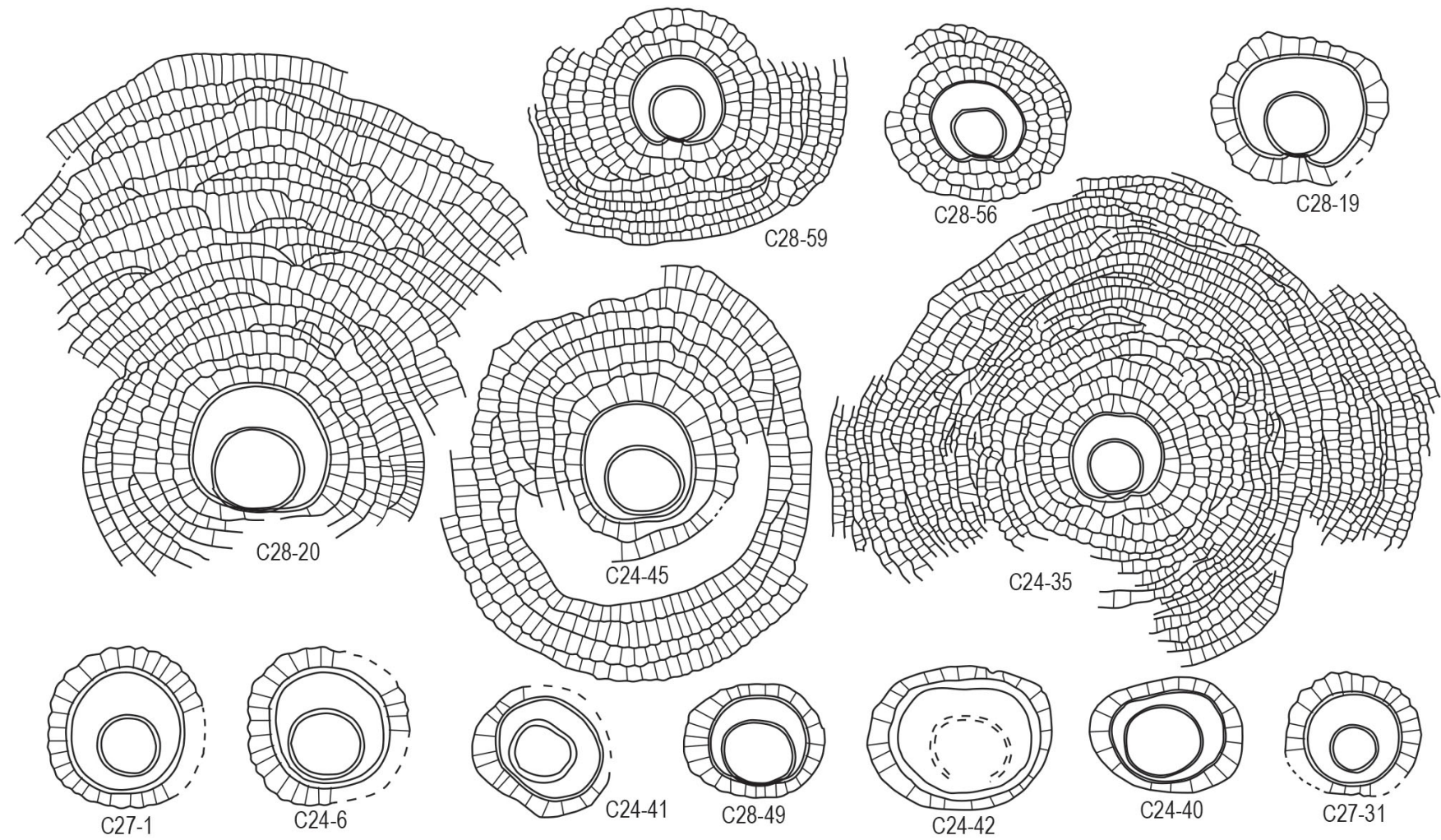

Figure 11. Embryon and equatorial chambers in Orbitoclypeus multiplicatus haymanaensis-multiplicatus. Note that the embryon is of excentrilepidine, umbilicolepidine, and trybliolepidine type, the equatorial chambers are incomplete, the distal sides of the chamberlets are arcuate to wedge shaped, and the peripheral chambers are radially elongated. The holotype of Orbitoclypeus multiplicatus haymanaensis from the Thanetian of Haymana Basin (central Turkey), sample KAR.8, is illustrated for comparison (Özcan et al., 2001). 


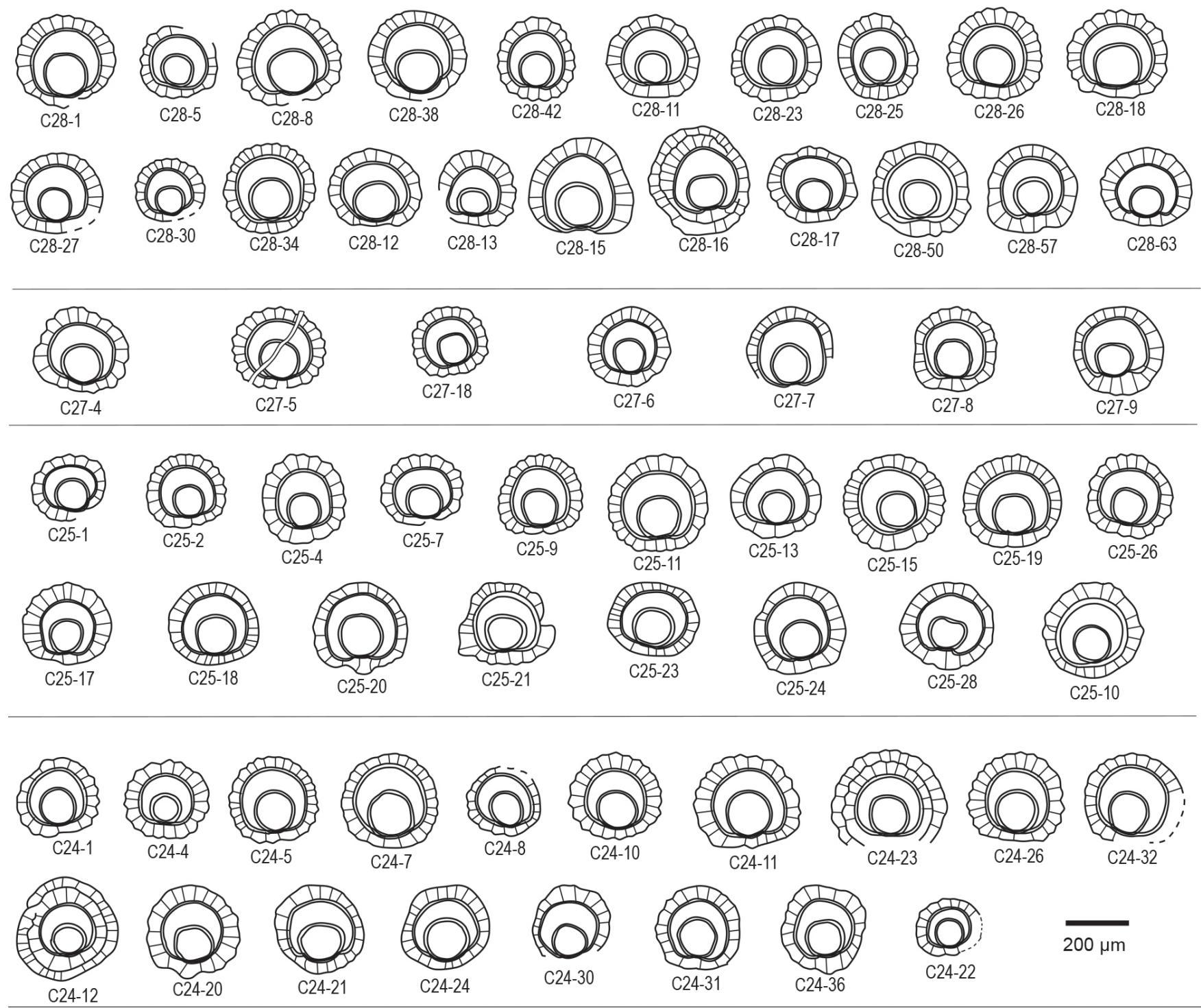

Figure 12. Variation in the embryon and configuration of the embryonic chambers in Orbitoclypeus schopeni ramaraoi-neumannae in samples C24, 25, 27, and 28 .

annular chamberlets are typically arched or wedge shaped. It commonly occurs in the orthophragminid assemblages from SW France to India, especially in the Thanetian and Ypresian. The earliest appearance is known from the lower Thanetian beds from India and SW France, with its reported highest occurrence from the late Lutetian (OZ 11) of Padragkút (Hungary) and San Pancrazio (OZ 12) (Italy). This species includes five subspecies in western Tethys: $O$. s. ramaraoi Samanta $\left(D_{\text {mean }}<195 \mu \mathrm{m}\right), O$. s. neumannae Toumarkine $\left(D_{\text {mean }}=195-240 \mu \mathrm{m}\right), O$. s. suvlukayensis Less $\left(D_{\text {mean }}=\right.$ 240-300 $\mu \mathrm{m}), O$. s. crimensis Less $\left(D_{\text {mean }}=300-500 \mu \mathrm{m}\right)$, and $O$. s. schopeni Checchia-Rispoli $\left(D_{\text {mean }}>500 \mu \mathrm{m}\right)$.
Orbitoclypeus schopeni (Checchia-Rispoli, 1908) ramaraoi (Samanta, 1967)-neumannae (Toumarkine, 1967): figs. 8.1-2, 9-13, 9.1-9, 10, $12,13.4-13$.

1967 Discocyclina ramaraoi n. sp. - Samanta: pp. 239-240, pl. 1, figs. 1-20, text-figs. 2-5.

1967 Discocyclina neumannae n. sp. Toumarkine: pp. 210-212, pl. 1, figs. 1-8.

1987 Orbitoclypeus ramaraoi ramaraoi (Samanta) - Less: pp. 197-198, text-fig. 30b. 

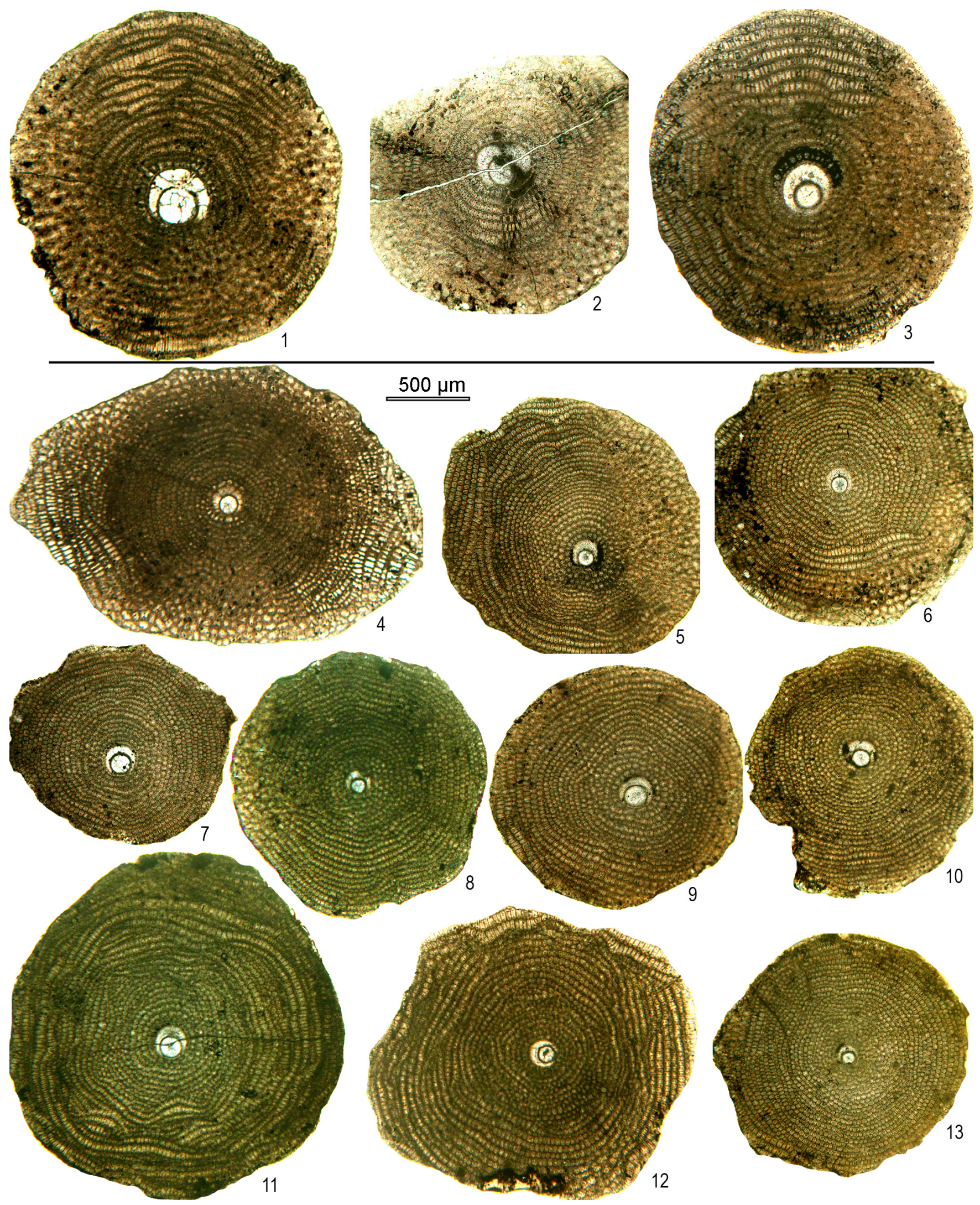

Figure 13. 1-3: Orbitoclypeus multiplicatus haymanaensis-multiplicatus; equatorial sections, 1: C28-20, 2: C28-19, 3: C27-1. 4-13: Orbitoclypeus schopeni ramaraoi-neumannae; equatorial sections, 4: C28-23, 5: C28-27, 6: C28-42, 7: C28-34, 8: C28-5, 9: C28-18, 10: C28-17, 11: C28-1, 12: C28-25, 13: C28-30. 

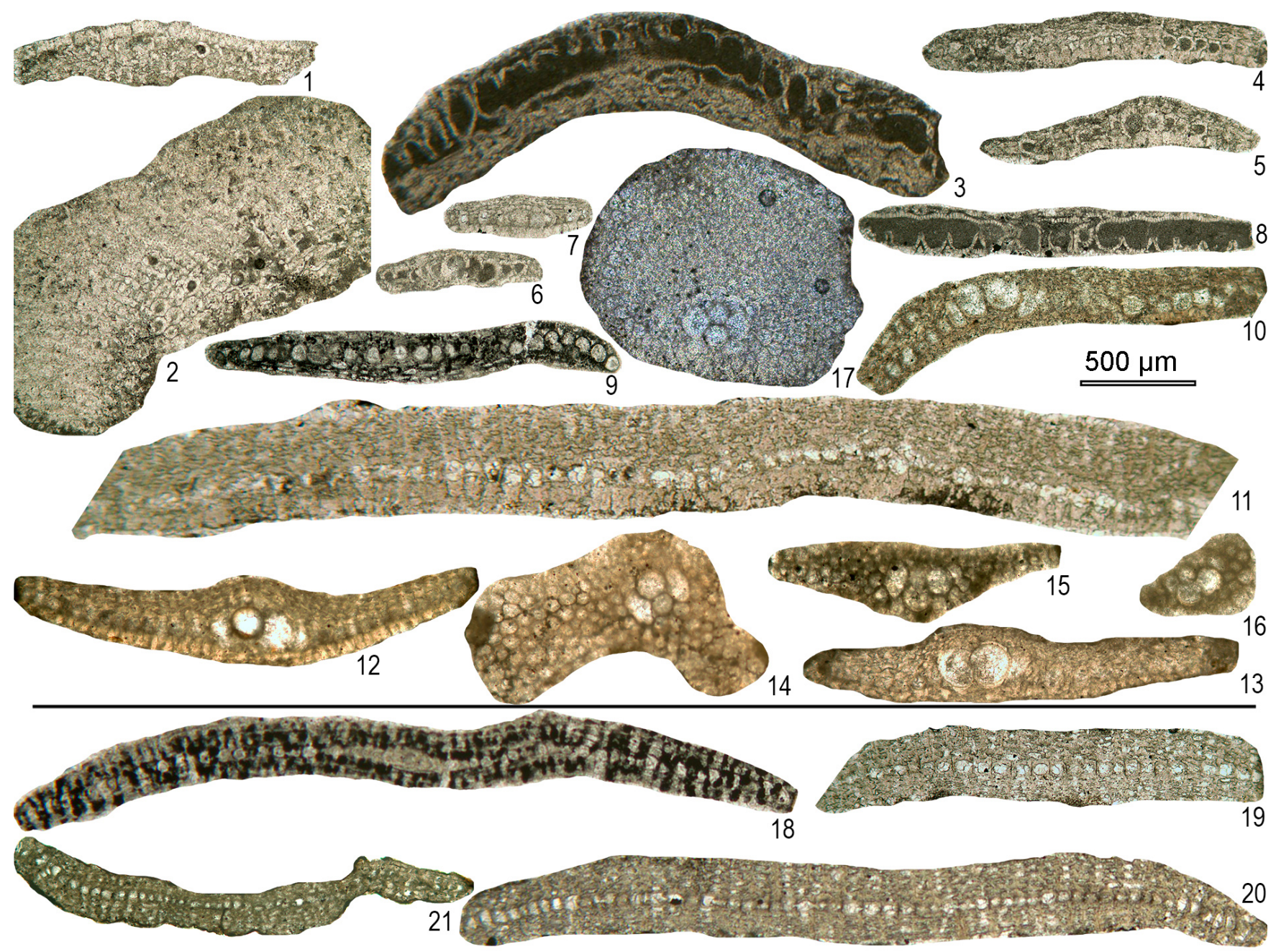

Figure 14. Orbitoidiform foraminifers from the Lakadong Limestone. 1-5: Lakadongia sp.; 1, 3-5; off-center axial sections, 1: C2-23, 3: C2A-1, 4: C2A-13, 5: C2A-18, 2: section showing equatorial chambers, C2-39. 6-17: Lakadongia tibetica; 6-11; off-center axial sections, 6: C10-1, 7: C11-6, 8: C11-10, 9: C12-25, 10: C18-8, 11: C18A-4. 12-13: axial sections, 12: C18-3, 13: C16-62. 14-17: incomplete equatorial sections. 14: C12-9, 15: C12-7, 16: C16A-1, 17: C16. 18-21: Orbitosiphon punjabensis; off-center axial sections, 18: C10-4, 19: C12-1, 20: C12-20, 21: C8-4.

1987 Orbitoclypeus ramaraoi (Samanta) neumannae (Toumarkine) - Less: pp. 198-199, pl. 26, figs. 1, 2, text-fig. 30c.

2001 Orbitoclypeus neumannae (Toumarkine) Özcan et al.: pp. 347, 348, 350, pl. 1, figs. 14-16, pl. 2, figs. 1-8, text-fig. 3C.

2007 Orbitoclypeus schopeni (Checchia-Rispoli) ramaraoi (Samanta) - Less et al.: pp. 441-442, pl. 3, figs. 20-22, Fig. 14.

2007 Orbitoclypeus schopeni (Checchia-Rispoli) neumannae (Toumarkine) - Less et al.: pp. 441442, pl. 3, figs. 19, 23-29, Fig. 14.

2010 Orbitoclypeus ramaraoi (Samanta) - Matsumaru and Sarma: pl. 6, fig. 8.
2010 Orbitosiphon tibetica (Douvillé) - Matsumaru and Sarma: pl. 1, fig. 3.

2014 Orbitoclypeus schopeni (Checchia-Rispoli) ramaraoi (Samanta) - Özcan et al.: pp. 224-225, fig. 12.10-14, fig. 13-14, fig. 15.13-16.

Both the megalospheric (A forms) and microspherical (B forms) specimens have been studied, though the microspherical generation is rare and only five specimens were found among 143. The test is of medium size, circular in outline, mostly symmetrical with regard to the equatorial layer, and lenticular discoidal. The test diameter and thickness in A forms range between 1050 and 2800 and between 350 and $780 \mu \mathrm{m}$, respectively (Fig. 8.7-13). In the lower part of the section (e.g., samples C3, 5, 9), the specimens (O. schopeni cf. ramaraoi) have smaller tests, varying in 
diameter from 600 to $1200 \mu \mathrm{m}$ (Fig. 8.3-6). The surface is smooth with uniformly distributed piles, coarser at the central part of the test $(70-90 \mu \mathrm{m}$ in diameter) and finer towards the periphery $(20-50 \mu \mathrm{m}$ in diameter). A large pile, $100-110 \mu \mathrm{m}$ in diameter, is usually observed at the center of the test. The equatorial layer is about $35-60 \mu \mathrm{m}$ high in axial sections. The average diameters of protoconch and deuteroconch range between 115.7-119.5 $\mu \mathrm{m}$ and 192.9-198.3 $\mu \mathrm{m}$, respectively (Table 1). Both chambers invariably exhibit a eulepidine-type embryonic configuration. The number of adauxiliary chamberlets counted in 132 specimens varies between 13 and 23 . The equatorial chamberlets are low and narrow in the early chambers and become radially elongated in the outer chambers. These chambers are slightly wavy in the equatorial sections and they usually form incomplete cycles (Fig. 10). The microspherical generation possesses a typical orbitoclypeid juvenarium, as shown in Fig. 8.22-24.

Remarks: Specimens from the lower part of the Lakadong Limestone (samples C3, 5, 9), as well as upper samples below sample C21 (Fig. 8.3-8), were assigned to Orbitoclypeus schopeni $\mathrm{cf}$. ramaraoi due to sparse morphometric data from these levels. Specimens from the upper part (SBZ 4) represent transitional development stages between $O$. schopeni ramaraoi and $O$. schopeni neumannae with average $D_{\text {mean }}$ values ranging between 192.9 and $198.3 \mu \mathrm{m}$ (Table 1). Orbitoclypeus schopeni is differentiated from O. multiplicatus in having (a) a smaller embryon, (b) a different type of embryonic configuration (eulepidine in $O$. schopeni and excentrilepidine to umbilicolepidine type in O. multiplicatus), (c) a smaller number of adauxiliary chamberlets, and (d) smaller equatorial chambers/chamberlets, as recorded in parameter $N_{0.5}$. The average deuteroconch size of this species from SBZ 4 in MQS is slightly above the morphometric limit between $O$. s. ramaraoi, which stratigraphically extends to the early Eocene in the western Tethys, and $O$. s. neumannae. These records suggest that the average deuteroconch size of $O$. schopeni might be slightly larger than that in the western Tethys (Table 2).

In previous works, Orbitoclypeus from the Lakadong Limestone has been apparently confused with the genera Discocyclina and Lakadongia. Matsumaru and Sarma (2010) illustrated several embryons in equatorial and uncentered equatorial sections as Orbitosiphon tibetica (Douvillé) from the Lakadong Limestone in Meghalaya. In fact, these specimens with different embryonic configurations and different features of equatorial chamberlets represent three different genera. The biloculine specimens illustrated in Plate 1, figs. 1 and 2 in Matsumaru and Sarma (2010) were correctly assigned to Orbitosiphon tibetica by the authors. The uncentered specimen with eulepidine embryon (fig. 3) represents an Orbitoclypeus schopeni ramaraoi and the specimen with isolepidine embryon and hexagonal peripheral chamberlets illustrated in fig. 4 represents a Nemkovella stockari Less \& Özcan (see Özcan et al., 2016a). We think that the strati- graphic position of Nemkovella stockari, an early Eocene species as recorded in several localities (e.g., Turkey, Tunisia, Egypt, and Oman) in the western Tethys, has also been confused by the authors. The alleged occurrence of Discocyclina in the Lakadong Limestone (e.g., Jauhri et al., 2006) is not confirmed by the present study. Previous records of orthophragminids from Pondicherry (SE India), the Salt Range (Pakistan), Gamba and Tingri (Tibet) (Samanta, 1967; Hu et al., 1976; Wan, 1991; Ferràndez-Cañadell, 2002; Wan et al., 2010; Zhang et al., 2013), and the late Paleocene and early Eocene assemblages from the Indian subcontinent (Özcan et al., 2015, and this study) suggest that the genera Discocyclina and Orbitoclypeus do not co-occur in the Paleocene of the eastern Tethys. The co-occurrence of both genera is known from the Alveolina vredenburgi beds (SBZ 5) in the Salt Range and lower Eocene Patala Formation in Thal in Pakistan (Özcan et al., 2015; Ercan Özcan, unpublished data, 2015).

\section{Orbitoclypeus multiplicatus (Gümbel, 1870)}

Diagnosis: Average-sized, inflate, unribbed forms with marthae type rosette. The medium-sized to moderately large embryon is in most cases excentrilepidine, rarely eulepidine. The numerous varians type adauxiliary chamberlets as well as the equatorial chamberlets are rather wide and of average height. The annuli are usually moderately undulated; the growth pattern is of the varians type. This species includes four subspecies in the western Tethys: O. m. haymanaensis Özcan, Sirel, Özkan-Altıner and Çolakoğlu $\left(D_{\text {mean }}<310 \mu \mathrm{m}\right) ; O$. m. multiplicatus Gümbel $\left(D_{\text {mean }}=310-420 \mu \mathrm{m}\right) ; O$. m. kastamonuensis Less and Özcan $\left(D_{\text {mean }}=420-550 \mu \mathrm{m}\right)$, and $O . m$. gmundenensis Less $\left(D_{\text {mean }}>550 \mu \mathrm{m}\right)$.

Orbitoclypeus multiplicatus (Gümbel, 1870) haymanaensis Özcan et al., 2001 -multiplicatus (Gümbel, 1870): Figs. 8.14-21, 9.10-13, 11, 13.1-3.

2001 Orbitoclypeus haymanaensis n. sp. - Özcan et al.: pp. 344-345, 347, pl. 1, figs. 1-13, textfig. 3A.

2007 Orbitoclypeus multiplicatus (Gümbel, 1870) haymanaensis Özcan, Sirel, Özkan-Altıner and Çolakoğlu, 2001 - Less et al.: pp. 439, pl. 3, figs. 1-3; Fig. 14.

2007 Orbitoclypeus multiplicatus multiplicatus (Gümbel, 1870) - Less et al.: pp. 439, pl. 3, figs. 59, 11-13; Fig. 14.

2014 Orbitoclypeus multiplicatus (Gümbel, 1870) haymanaensis Özcan, Sirel, Özkan-Altıner and Çolakoğlu, 2001 - Özcan et al.: pp. 223, figs. 12, 15-19, 21-25, Figs. 13-14, 19.

Only megalospheric (A forms) specimens have been found. The test is of medium size, circular in outline, 
Table 2. Statistical data for O. schopeni ramaraoi from western Tethys. "No." denotes the number of specimens studied in the samples.

\begin{tabular}{llrrr}
\hline Sample \& locality & SBZ and Reference & No. & $P_{\text {mean }}$ & $D_{\text {mean }}$ \\
\hline KURUC-Turkey & SBZ 5 (Less et al., 2007) & 18 & 106.2 & 185.8 \\
KAR.8-Turkey & SBZ 3-4 (Özcan et al., 2001) & 20 & 108.5 & 183.4 \\
KAR.9-Turkey & SBZ 3-4 (Özcan et al., 2001) & 12 & 115.0 & 188.7 \\
D6.37-Egypt & SBZ 3-4 (Özcan et al., 2014) & 4 & 100.0 & 181.2 \\
D8.20-Egypt & SBZ 3-4 (Özcan et al., 2014) & 5 & 91.7 & 173.0 \\
D5.38-Egypt & SBZ 3-4 (Özcan et al., 2014) & 5 & 98.0 & 185.0 \\
B3.41-Egypt & SBZ 3-4 (Özcan et al., 2014) & 7 & 95.8 & 185.7 \\
NTSOR-France & SBZ 3 (Less et al., 2007) & 4 & 137.5 & 192.5 \\
RUBEC-France & SBZ 3 (Less et al., 2007) & 11 & 108.6 & 184.5 \\
\hline
\end{tabular}

mostly symmetrical with regard to the equatorial layer, and lenticular discoidal with a lobate periphery. The external test features are similar to those of $O$. schopeni and a clear distinction based on these features between these two species is not possible. The test diameter and thickness in A forms range between 1780 and 2050 and between 650 and $800 \mu \mathrm{m}$, respectively (Fig. 8.14-21). The surface is smooth with uniformly distributed piles, coarser in the central part of the test $(50-100 \mu \mathrm{m}$ in diameter) and finer towards the periphery $(30-50 \mu \mathrm{m}$ in diameter). A large pile is usually present at the center of the test. The equatorial layer is about $50-55 \mu \mathrm{m}$ high in axial sections. The average diameters of the protoconch and deuteroconch range between 150.0189.0 and $300.0-318.3 \mu \mathrm{m}$, respectively (Table 1). Both chambers exhibit excentrilepidine to umblicolepidine embryonic configuration (Fig. 11). The number of adauxiliary chamberlets counted in 27 specimens varies between 24 and 32. The equatorial chamberlets are relatively high and wide in the early chambers and may become radially elongated in the outer chambers. These chambers are slightly wavy in the equatorial sections and they usually form incomplete cycles (Fig. 11).

Remarks: O. multiplicatus, identified only in the upper part of the MQS, is much less abundant than O. schopeni. A distinction between $O$. multiplicatus and $O$. schopeni based on external characters is unfeasible because of the same test features; these species can be differentiated only in equatorial and axial sections. Less et al. (2007) indicated that the morphology and the evolutionary track of Orbitoclypeus multiplicatus and $O$. schopeni and $O$. varians are very similar. Therefore, the assignment of a given population to any of these three species is based mainly on the accompanying fossils. Moreover, they all gave rise to coeval lineages with ribs such as $O$. bayani, $O$. munieri, and $O$. furcatus, respectively, that are also very similar to each other.

\section{The orbitoidiform foraminifera in MQS}

The orbitoidiform foraminifers in MQS include two genera, Lakadongia Matsumaru and Jauhri, 2003, very common in SBZ 3 and rare in SBZ 4, and sparse Orbitosiphon Rao in SBZ 4 (Figs. 5 and 14). The orbitoidiform genus Setia, with type species Lepidorbitoides tibetica Douvillé from the Thanetian of Tibet, was introduced by FerràndezCañadell (2002), who demonstrated that its architecture differs from that of the related and largely coeval genus $\mathrm{Or}$ bitosiphon Rao; both genera are restricted to Tibet, Pakistan, and India. Unfortunately, the name Setia was preoccupied by Setia Adams and Adams (Gastropoda: Rissoidae), a circumstance of which its author was not aware at that time (Carles Ferràndez-Cañadell, personal communication, 2010). Later, Matsumaru and Jauhri (2003) established the orbitoidiform foraminiferal genus Lakadongia from the Thanetian of Meghalaya, with type species Lakadongia indica Matsumaru and Jauhri. In turn, Ferràndez-Cañadell (2004) demonstrated $L$. indica to be a junior synonym of "Setia" tibetica Douvillé. Finally, unaware of Matsumaru and Jauhri (2003) and Ferràndez-Cañadell (2004), Özdikmen (2009) recognized that the name Setia Ferràndez-Cañadell, 2002 is preoccupied by Setia Adams and Adams and proposed the replacement name Novosetia. Notwithstanding the issue of the nomenclatural unavailability of the electronic publication in which it was published (Huber, 2007; ICZN, 2012), the genus-group name Novosetia Özdikmen is also invalid because there is an earlier available senior synonym, i.e., Lakadongia Matsumaru and Jauhri. This is in accordance with the Principle of Priority, as set forth by the ICZN (1999: Art. 23): if a scientific name is found to be unavailable or invalid, it must be replaced by the next oldest available name among its synonyms. Thus, the valid name for Setia Ferràndez-Cañadell is Lakadongia Matsumaru and Jauhri. The genus Lakadongia therefore includes two species, $L$. primitiva (Ferràndez-Cañadell, 2002) from the Hangu Formation, and the stratigraphically higher Lakadongia tibetica Douvillé from the Lockhart Limestone in the Salt Range in Pakistan. As of yet, this is the only locality where these Paleocene orbitoidiform foraminifers were studied in de- 
tail and the evolution of both genera has been recorded (Ferràndez-Cañadell, 2002). The Lockhart Limestone is generally considered upper Paleocene, although a firm shallow benthic zonation of the formation has not been proposed yet. Thus, the stratigraphic distribution of Lakadongia and Orbitosiphon and their species in the Lockhart Limestone are not well constrained in terms of SBZ. Our data from the Lakadong Limestone suggest that Lakadongia extends from SBZ 3 to 4, although it is rare in SBZ 4. This, however, may be due to facies change recorded by the prevalence of orthophragminids in the upper part of MQS. Due to lack of information for the embryonic stage of the genus, no species attribution was made for the specimens in the lower part of the section. Specimens of Lakadongia from the middle part of the MQS with two "first embryonic chambers" are confidently assigned to L. tibetica (Fig. 14.14-17). Orbitosiphon is poorly known from the MQS and only a few tangential sections are available (Fig. 14.18-21); thus its stratigraphic range cannot be precisely established.

\section{Significance of the transition from a marine to continental depositional setting in MQS}

The late Paleocene to early Eocene corresponds to widespread shallow-marine sedimentation (mainly carbonates) along the northern margin of the Indian plate. Apart from other geological tools, stratigraphic development of the Paleogene sequences on the Indian craton was used as a tool to pinpoint the onset of the collision of the Indian and Asian plates (see Hu et al., 2016, for a synthesis and references therein). These deposits were investigated from Tethyan Himalayas, e.g., the Dibling and Zongpu formations (Garzanti et al., 1987; Green et al., 2008; Zhang et al., 2013; Jiang et al., 2015; Hu et al., 2016), and from the foreland basins in the sub-Himalayas, e.g., the Lockhart Limestone and Dungan Formation in the Salt Range and Sulaiman Range in Pakistan, and the Subathu and Dibling formations in northwest India (Najman et al., 2004; Afzal et al., 2011; Zhang et al., 2012) (Fig. 15). The cessation of the (shallow) marine sedimentation in the shelf and transition to continental setting, deposition of a laterally widespread conglomerate bed within the shallow-marine carbonates marking a break in sedimentation, and shoaling of the outer shelf deposits at or close to the Paleocene-Eocene boundary were commonly linked to the flexural uplift of the passive margin, marking the onset of the collision of the Indian and Eurasian plates (Garzanti et al., 1987; Zhang et al., 2012). In addition, thrusting of accretionary prism and trench complex over the Paleocene passive margin deposits was interpreted to hint the early sign for the onset of a collision (Beck et al., 1995). Nevertheless, a variety of ages ranging from Late Cretaceous to OligoceneMiocene were assigned to the India-Asia collision based upon the various other criteria and hypotheses (see Hu et al., 2016, and references therein). The Paleocene-Eocene sec- tions from the Shillong Plateau, which corresponds to the most eastern part of the foreland, however, were not taken into consideration in these reconstructions. Our data from Mawmluh show a sharp facies change from shallow-marine carbonates (Lakadong Limestone) to coal-bearing continental sandstones (the Lakadong sandstone) within SBZ 4. This corresponds to the oldest record for the cessation of marine carbonate sedimentation among the reported passive continental margin deposits (Fig. 15). Lakadong sandstone, ca. 25-250 m thick, consists of arkosic sandstone with thin carbonaceous shale and coal seams and is interpreted to have deposited in estuarine and lagoonal environments (Singh and Singh, 2000). Prasad et al. (2006) recorded the PaleoceneEocene Thermal Maximum within the Lakadong sandstone and considered a significant part of the unit to be of Thanetian age. Our interpretation is that the drastic facies change in the MQS from a marine to continental setting within SBZ 4 corresponds to the oldest record for the cessation of the carbonate deposition along the passive margin. This was previously reported to be SBZ 6, which corresponds to a conglomerate horizon within the carbonates in the Gamba section in the Tethyan Himalayas (Zhang et al., 2012; Li et al., 2017).

\section{Discussion and conclusions}

The Lakadong Limestone, a ca. $36 \mathrm{~m}$ thick shallow-marine limestone-dolomite unit with fine-clastic intercalations in MQS, can be referred to the shallow benthic zones SBZ 3 and 4 , based on the presence of alveolinids, miscellaneids, rotaliids, and some orbitoidiform taxa, the latter group being endemic to the eastern Tethys. The coralline and dasycladalean algae are the main floral elements. The LBF and associated fauna and flora suggest a general deepening upsection from an inner to middle shelf depositional setting. Orthophragminids, rare in the lower and middle and very common in the upper part of the MQS, are subdivided into two lineages of the genus Orbitoclypeus Silvestri, O. schopeni (Checchia-Rispoli), and O. multiplicatus (Gümbel). The distinction of both species externally is unfeasible, due to similar test features, whereas in equatorial sections both species are differentiated based on the embryonic configuration, embryon size, and features of equatorial chambers. Orbitoclypeus schopeni is represented by the phylogenetically most primitive subspecies, $O$. schopeni ramaraoi, in the lower part of the section and by a transitional developmental stage of $O$. schopeni ramaraoi and $O$. schopeni neumannae in the upper part. Orbitoclypeus multiplicatus, however, represents a transitional stage between $O$. multiplicatus haymanaensis and O. multiplicatus multiplicatus. Comparing the embryon size of both species in the section with those of the specimens from the coeval taxa from the western Tethys, we infer that the embryon of both taxa is slightly larger in the eastern Tethys. Orbitoclypeus multiplicatus is recorded here for the first time from the eastern Tethys and its ge- 

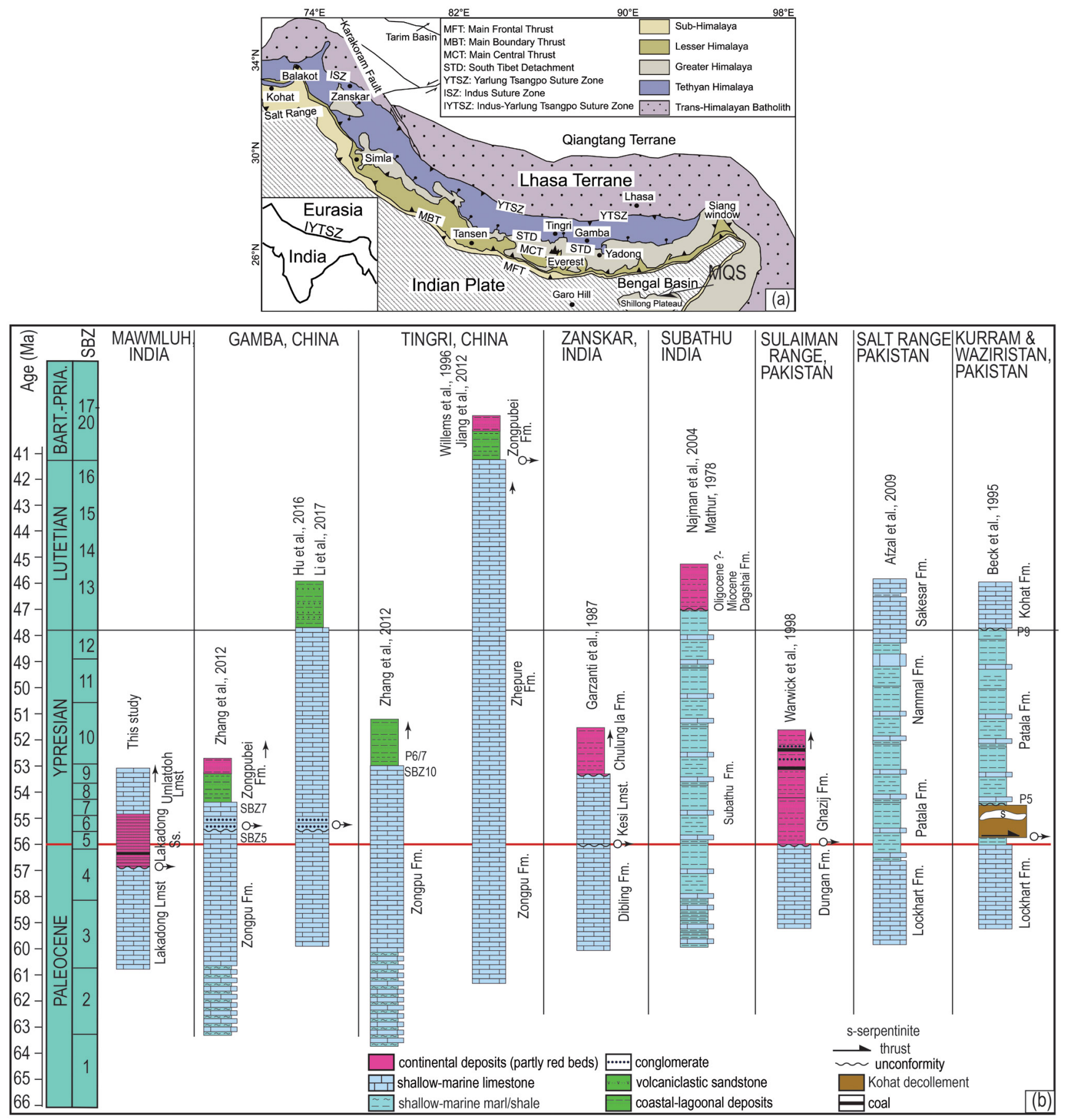

Figure 15. Stratigraphic columns of selected areas showing the correlation of Paleocene-early Eocene shallow marine sections in the Himalayan foreland basin in China, India, and Pakistan. A break in the sedimentation across the Paleocene-Eocene boundary is marked by an arrow. The map of Himalaya orogeny is from Jiang et al. (2015).

ographic distribution is extended from eastern Europe and North Africa to northern India (Fig. 16). The absence of Discocyclina, a common late Paleocene orthophragminid genus in the western Tethys, from the Paleocene Himalayan foreland basins and southern India, is significant for the eval- uation of the Eocene development of eastern Tethyan orthophragminids. The stratigraphically oldest Discocyclina assemblage in the Indian subcontinent has been recorded from the lower Eocene succession of the Patala Formation in Thal in Pakistan and is represented by Discocyclina 


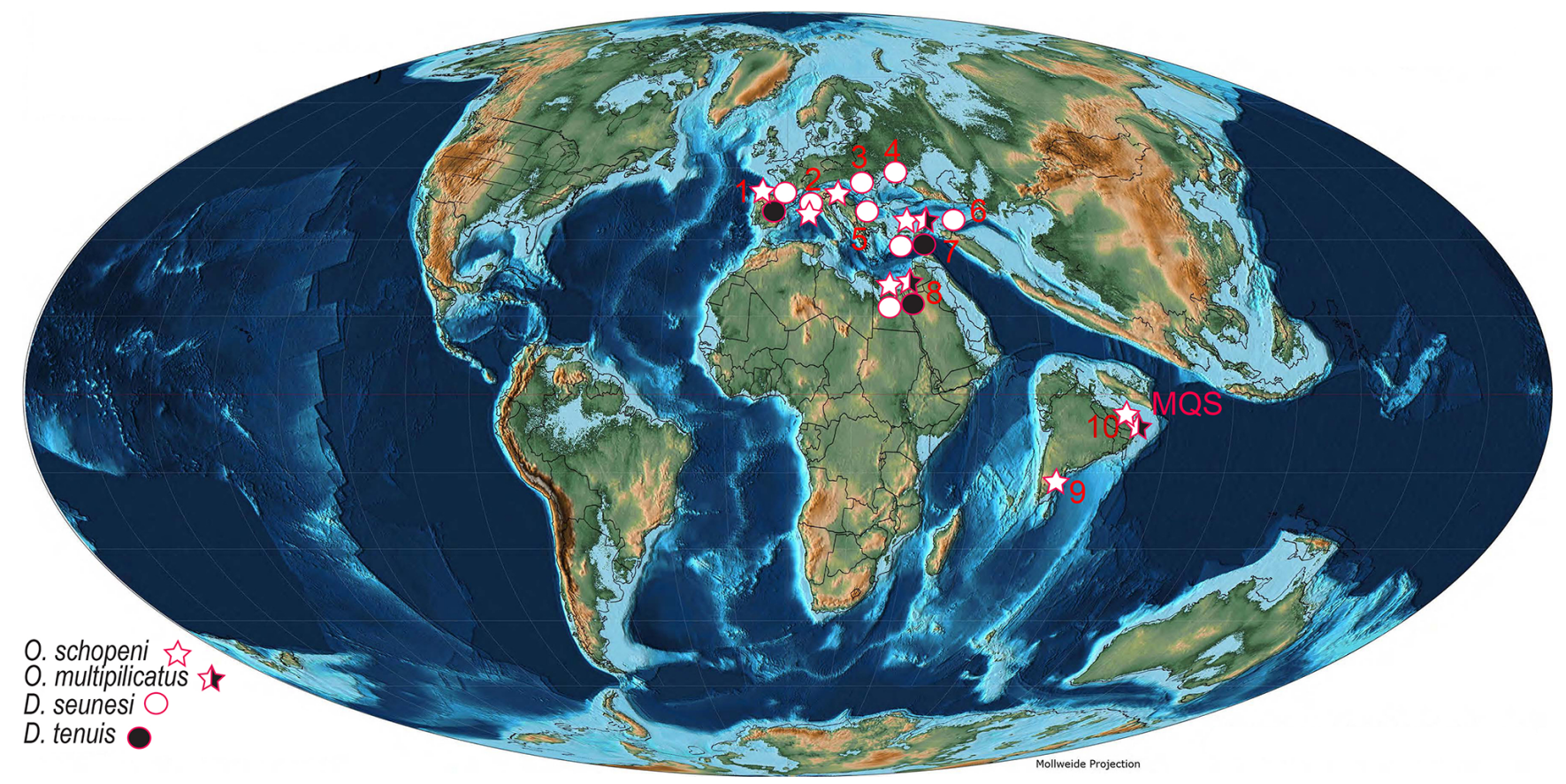

Figure 16. Distribution of Tethyan late Paleocene orthophragminids on late Paleocene-early Eocene paleogeographic base map (updated from Özcan et al., 2014). 1: Aquitaine Basin (France): Schlumberger (1903), Douvillé (1922), Neumann (1958), and Less (1998). 2: Adriatic Carbonate Platform (Slovenia): Drobne et al. (2012). 3: western Carpathians (Slovakia): Samuel et al. (1972). 4: central and eastern Crimea: Zernetskii (1977), and Zakrevskaya (2007). 5: Bulgaria: Less et al. (2007). 6: Armenia: Grigoryan (1986). 7: Haymana Basin (Turkey): Özcan et al. (2001). 8: Galala (Egypt): Özcan et al. (2014). 9: southern India: Samanta (1967). 10: Meghalaya (NE India).

ranikotensis, $D$. archiaci, $D$. dispansa, and $D$. aff. fortisi. Both Discocyclina ranikotensis and D. aff. fortisi are endemic to the Indian subcontinent and the embryon size of $D$. archiaci also appears to be slightly larger than that of the western Tethyan D. archiaci (Özcan et al., 2015). Combining the orthophragminid records from Meghalaya, Pondicherry, in SE India and the lower Eocene Patala Formation in Thal, Pakistan, and taking into account the published evidence on Paleocene LBF assemblages from the southern Asian and Indian margins, we maintain that Orbitoclypeus was the sole orthophragminid genus in the Paleocene of eastern Tethys and Discocyclina only appeared in early Eocene times with predominant endemic taxa confined to the Indian subcontinent.

Data availability. The material can be accessed at the Geology Department of İstanbul Technical University.

Competing interests. The authors declare that they have no conflict of interest.

Acknowledgements. We thank the editor (Kirsty Edgar) and the two reviewers (Gyorgy Less and the anonymous referee) for their valuable remarks and suggestions. We also gratefully acknowledge the management of Mawmluh Cherra Cements Ltd. for permission to sample the limestone quarry. Fieldwork in India was possible due to funding by TUBA (Turkish Academy of Sciences) and INSA (Indian National Science Academy) Exchange of Scientists to Ercan Özcan and funding for laboratory work to Pratul Kumar Saraswati.

TMS Promoted Paper 2018

Edited by: Kirsty Edgar

Reviewed by: Less György and one anonymous referee

\section{References}

Adams, H. and Adams, A.: On a new arrangement of British Rissoae, Ann. Mag. Nat. Hist., 10, 358-359, 1852.

Afzal, J., Williams, M., and Aldridge, R. J.: Revised stratigraphy of the lower Cenozoic succession of the Greater Indus Basin in Pakistan, J. Micropalaeontol., 8, 7-23, 2009.

Afzal, J., Williams, M., Leng, M. J., and Aldridge, R.: Dynamic response of the shallow marine benthic ecosystem to regional and pan-Tethyan environmental change at the Paleocene-Eocene boundary, Palaeogeogr. Palaeocl., 309, 141-160, 2011.

Barattolo, F.: Late Cretaceous-Paleogene dasycladaleans and the K/T Boundary problem, in: Research advances in calcareous algae and microbial carbonates, edited by: Bucur, I. and Filipescu, S., 19-40, Cluj University Press, 2002. 
Beck, R. A., Burbank, D. W., Sercombe, W. J., Riley, G. W., Barndt, J. K., Berry, J. R., Afzal, J., Khan, A. M., Jurgen, H., Metje, J., Cheema, A., Shafique, N. A., Lawrence, R. D., and Khan, M. A.: Stratigraphic evidence for an early collision between northwest India and Asia, Nature, 373, 55-58, 1995.

Biswas, S., Coutand, I., Grujic, D., Hager, C., Stöckli, D., and Grasemann, B.: Exhumation and the uplift of the Shillong plateau and its influence on the eastern Himalayas: new constraints from apatite and zircon (U-Th-[Sm])/He and apatite fission track analyses, Tectonics, 26, TC6013, https://doi.org/10.1029/2007TC002125, 2007.

BouDagher-Fadel, M. K. and Price, G. D.: The Paleogeographic evolution of the orthophragminids of the Paleogene, J. Foramin. Res., 47, 337-357, 2017.

BouDagher-Fadel, M. K., Price, G. D., Hu, X., and Li, J.: Late Cretaceous to early Paleogene foraminiferal biozones in the Tibetan Himalayas, and a pan-Tethyan foraminiferal correlation scheme, Stratigraphy, 12, 67-91, 2015.

Checchia-Rispoli, G.: Nota preventiva sulla serie nummulitica dei dintorni di Bagheria e di Termini-Imerese in prov. di Palermo, Giornale di Scienze Naturali ed Economiche, 26, 1-35, 1908.

Douvillé, H.: Révision des Orbitoïdes. Deuxième partie: Les Orthophragmina du Danien et de l'Éocène, B. Soc. Geol. Fr., 22, 55-100, 1922.

Drobne, K.: Alvéolines paléogenes de la Slovénie et de l'Istrie, Schweizerische Paläontologische Abhandlungen, 99, 1-175, 1977.

Drobne, K., Bartol, M., Premec-Fuček, V., Schenk, B., Ćosović, V., and Pugliese, N.: Microfauna and nannoplankton below the Paleocene/Eocene transition in hemipelagic sediments at the southern slope of Mt. Nanos (NW part of the Paleogene Adriatic carbonate platform, Slovenia), Austrian J. Earth Sc., 105/1, 208-223, 2012.

Drobne, K., Jež, J., Ćosović, V., Ogorelec, B., Stenni, B., Zakrevskaya, E., and Hottinger, L.: Identification of the PaleoceneEocene boundary based on larger foraminifers on the Paleogene Adriatic carbonate platform (PgAdCP) (section Sopada, Vrhpolje, SW Slovenia), in: STRATI 2013, edited by: Rocha, R., Pais, J., Kullberg, J. C., and Finney, S., Springer Geology, Cham, Switzerland, 89-94, 2014.

Dutta, S. K. and Jain, K. P.: Geology and palynology of the area around Lumshnong, Jaintia Hills, Meghalaya, India, Biological Memoirs, 5, 56-81, 1980.

Ferràndez-Cañadell, C.: A new, ribbed species of Nemkovella 1987 (Discocyclinidae), and discussion on the genus Actinocyclina Gümbel, 1870., J. Foramin. Res., 27, 175-185, 1997.

Ferràndez-Cañadell, C.: Morphostructure and paleobiology of Mesogean orthophragminids (Discocyclinidae and Orbitoclypeidae, Foraminifera), Acta Geologica Hispanica, 31, 183-187, 1998.

Ferràndez-Cañadell, C.: New Paleocene orbitoidiform foraminifera from the Punjab Salt Range, Pakistan, J. Foramin. Res., 32, 1-21, 2002.

Ferràndez-Cañadell, C.: The foraminiferal genus Lakadongia Matsumaru and Jauhri 2003, a re-evaluation, Micropaleontology, 50, 397-400, 2004.

Garg, R. and Khowaja-Ateequzzaman, S.: Dinoflagellate cysts from the Lakadong sandstone, Cherrapunji area: biostratigraphical and paleoenvironmental significance and relevance to the sea level changes in the Upper Palaeocene of the Khasi Hills, South Shillong Plateau, India, Palaeobotanist, 49, 461-484, 2000.

Garzanti, E., Baud, A., and Mascle, G.: Sedimentary record of the northward flight of India and its collision with Eurasia (Ladakh Himalaya, India), Geodin. Acta, 1, 297-312, 1987.

Gogoi, B., Kalita, K. D., Garg, R., and Borgohain, R.: Foraminiferal biostratigraphy and palaeoenvironment of the Lakadong Limestone of the Mawsynram area, south Shillong Plateau, Meghalaya, J. Palaeontol. Soc. Ind., 54, 209-224, 2009.

Govindan, A.: Larger foraminiferal biostratigraphy of Early Paleogene sections in India, Geological Society of India, Special Publication, 1, 24-45, 2013.

Green, O. R., Searle, M. P., Corfield, R. I., and Corfield, R. M.: Cretaceous-Tertiary carbonate platform evolution and age of the India-Asia collision along the Ladakh Himalaya (northwest India), J. Geol., 116, 331-353, 2008.

Grigoryan, S. M.: Nummulitidy i orbitoidy Armânskoj SSR, Akademiâ Nauk Armânskoj SSR, Erevan, 216 pp., 1986.

Gümbel, C. W.: Beiträge zur Foraminiferenfauna der nordalpinen Eozängebilde oder der Kressenberger Nummuliten Schichten, Abhandlungen der Matematisch-Physikalischen Classe der Königlich Bayerischen Akademie der Wissenschaften, 10, 581$720,1870$.

Hottinger, L.: Recherches sur les Alvéolines du Paléocène et de l'Eocène, Schweizerische Paläontologische Abhandlungen, 75/76, 1-243, 1960.

Hottinger, L.: Paleogene larger rotaliid foraminifera from the western and central Neotethys, Springer, Switzerland, 196 p., 2014.

Hu, X., Garzanti, E., Wang, J., Huang, W., An, W., and Webb, A.: The timing of India-Asia collision onset - Facts, theories, controversies, Earth-Sci. Rev., 160, 264-299, 2016.

Hu, Y., Zhang, B., Hu, L. Y., and Sheng, J. C.: Mesozoic and Cenozoic foraminifera from the Mount Jolmo Lungma region, in: Scientific investigation to the Mount Jolmo Lungma region (19661968), Paleontology, Scientific Publishing House, China, 1-76, 1976 (in Chinese).

Huber, J. H.: Non-availability of a name electronically published: the case of Adamas Huber, 1979 (Pisces, Cyprinodontiformes, Nothobranchiidae), invalidly replaced on the Internet, Zoosystema, 29, 209-214, 2007.

ICZN: International Code of Zoological Nomenclature, Fourth Edition, The International Trust for Zoological Nomenclature, London, xxix+306 p., 1999.

ICZN: Amendment of Articles 8, 9, 10, 21 and 78 of the International Code of Zoological Nomenclature to expand and refine methods of publication, Bulletin of Zoological Nomenclature, 69, 161-169, 2012.

Jauhri, A. K.: Carbonate buildup in the Lakadong Formation of the south Shillong plateau, NE India: a micropaleontological perspective, in: Studies on ecology and paleontology of bentic communities, edited by: Matteucci, R., Carboni, M. G., and Pignatti J., Bollettino della Società Paleontologica Italiana, 2, 157-169, 1994.

Jauhri, A. K.: Miscellanea Pfender, 1935 (Foraminiferida) from the south Shillong region, NE India, J. Palaeontol. Soc. Ind., 43, 7383, 1998.

Jauhri, A. K. and Agarwal, K. K.: Early Palaeogene in the south Shillong Plateau, NE India: local biostratigraphic signal of the 
global tectonic and oceanic changes, Palaeogeogr. Palaeocl., 168, 187-203, 2001.

Jauhri, A. K., Misra, P. K., Kishore, S., and Singh, S. K.: Larger foraminiferal and calcareous algal facies in the Lakadong Formation of the south Shillong Plateau, NE India, J. Palaeontol. Soc. Ind., 51, 51-61, 2006.

Jiang, T., Aitchison, J. C., and Wan, X.: The youngest marine deposits preserved in southern Tibet and disappearance of the Tethyan Ocean, Gondwana Res., 32, 4-75, 2015.

Koley, T. and Wanjarwadkar, K. M.: First report of Ranikothalia Caudri from Middle Andaman Island, India and its significance, J. Geol. Soc. India, 81, 549-555, 2013.

Less, G.: Paleontology and stratigraphy of the European Orthophragminae, Geologica Hungarica series Palaeontologica, 51, 1-373, 1987.

Less, G.: Zonation of the Mediterranean Upper Paleocene and Eocene by Orthophragminae, Opera Dela Slovenska Akademija Znanosti in Umetnosti, 34, 21-43, 1998.

Less, G. and Kovács, Ó, L: Typological versus morphometric separation of orthophragminid species in single samples - a case study from Horsarrieu (upper Ypresian, SW Aquitaine, France), Revue de Micropaléontologie, 52, 267-288, 2008.

Less, G., Özcan, E., Báldi-Beke, M., and Kollányi, K.: Thanetian and early Ypresian orthophragmines (Foraminifera: Discocyclinidae and Orbitoclypeidae) from the central Western Tethys (Turkey, Italy and Bulgaria) and their revised taxonomy and biostratigraphy, Riv Ital. di Paleontol S., 113, 419-448, 2007.

Li, J., Hu, X., Garzanti, E., and BouDagher-Fadel, M.: Shallowwater carbonate responses to the Paleocene-Eocene thermal maximum in the Tethyan Himalaya (southern Tibet): Tectonic and climatic implications, Palaeogeogr. Palaeocl., 466, 153-165, 2017.

Mathur, N. S.: Biostratigraphical aspects of the Subathu Formation, Kumaun Himalayas, Rec. Res. Geol., 5, 96-112, 1978.

Matsumaru, K. and Jauhri, A. K.: Lakadongia, a new orbitoidal foraminiferal genus from the Thanetian (Paleocene) of Meghalaya, NE India, Micropaleontology, 49, 277-291, 2003.

Matsumaru, K. and Sarma, A.: Larger foraminiferal biostratigraphy of the lower Tertiary of Jaintia Hills, Meghalaya, NE India, Micropaleontology, 56, 539-565, 2010.

Nagappa, Y.: Foraminiferal biostratigraphy of the CretaceousEocene succession in the India-Pakistan-Burma region, Micropaleontology, 5, 145-192, 1959.

Najman, Y., Johnson, K., White, N., and Oliver, G.: Evolution of the Himalayan foreland basin, NW India, Basin Res., 16, 1-24, 2004.

Najman, Y., Bracciali, L., Parrish, R. R., Chisty, E., and Copley, A.: Evolving strain partitioning in the Eastern Himalaya: the growth of the Shillong Plateau, Earth Planet. Sc. Lett., 433, 1-9, 2016.

Nebelsick, J. H., Rasser, M. W., and Bassi, D.: Facies dynamics in Eocene to Oligocene circumalpine carbonates, Facies, 51, 197216, 2005.

Neumann, M.: Révision des Orbitoididés du Crétacé et de l'Eocène en Aquitaine occidentale, Mém. S. Géo. F., 83, 1-174, 1958.

Özcan, E., Sirel, E., Özkan-Altıner, S., and Çolakoğlu, S.: Late Paleocene Orthophragminae (Foraminifera) from the HaymanaPolatlı Basin (Central Turkey) and description of a new taxon, Orbitoclypeus haymanaensis, Micropaleontology, 47, 339-357, 2001.
Özcan, E., Scheibner, C., and Boukhalfa, K.: Orthophragminids (foraminifera) across the Paleocene/Eocene transition from North Africa: taxonomy, biostratigraphy and paleobiogeographic implications, J. Foramin. Res., 44, 203-229, 2014.

Özcan, E., Hanif, M., Ali, N., and Yücel, A. O.: Early Eocene orthophragminids (foraminifera) from the type-locality of Discocyclina ranikotensis Davies, 1927, Thal, NW Himalayas, Pakistan: insights into the orthophragminid paleobiogeography, Geodin. Acta, 27, 267-299, 2015.

Özcan, E., Abbasi, I. A., Drobne, K., Govindan, A., Jovane, L., and Boukhalfa, K.: Early Eocene orthophragminids and alveolinids from the Jafnayn Formation, N Oman: significance of Nemkovella stockari Less \& Özcan, 2007 in Tethys, Geodin. Acta, 28, 160-184, 2016a.

Özcan, E., Saraswati, P. K., Hanif, M., and Ali, N.: Orthophragminids with new axial thickening structures from the Bartonian of the Indian subcontinent, Geol. Acta, 14, 261-282, $2016 \mathrm{~b}$.

Özdikmen, H.: Substitute names for some unicellular animal taxa (Protozoa), Munis Entomology Zoology, 4, 233-256, 2009.

Papazzoni, C. A., Ćosović, V., Briguglio, A., and Drobne, K.: Towards a calibrated larger foraminifera biostratigraphic zonation: celebrating 18 years of the application of shallow benthic zones, Palaios, 32, 1-5, 2017.

Prasad, V., Garg, R., Ateequzzaman, K., Sing, I. B., and Joachimski, M. M.: Apectodinium acme and palynofacies characteristics in the latest Palaeocene-earliest Eocene of northeastern India: biotic response to the Palaeocene-Eocene Thermal Maxima (PETM) in low latitude, J. Palaeontol. Soc. Ind., 51, 75-91, 2006.

Samanta, B. K.: Discocyclina from the early Tertiary sediments of Pondicherry, south India, Micropaleontology, 13, 233-242, 1967.

Samanta, B. K.: Foraminiferal genus Ranikothalia Caudri from the Pondicherry Formation, Pondicherry South India, Quarterly Journal of the Mining and Metallurgical Society of India, 4, 121133, 1980.

Samuel, O., Borza, K., and Köhler, E.: Microfauna and lithostratigraphy of the Paleogene and adjacent Cretaceous of the Váh valley (west Carpathian), Geologický Ústav Dionýza Stúra, Bratislava, 246 p., 1972.

Schlumberger, C.: Troisième note sur les Orbitoïdes, B. Soc. Geol. Fr., 4, 273-289, 1903.

Serra-Kiel, J., Hottinger, L., Caus, E., Drobne, K., Ferràndez, C., Jauhri, A. K., Less, G., Pavlovec, R., Pignatti, J., Samsó, J. M., Schaub, H., Sirel, E., Strougo, A., Tambareau, Y., Tosquella, J., and Zakrevskaya, E.: Larger foraminiferal biostratigraphy of the Tethyan Paleocene and Eocene, B. Soc. Geol. Fr., 169, 281-299, 1998.

Singh, M. P. and Singh, A. K.: Petrographic characteristics and depositional conditions of Eocene coals of platform basins, Meghalaya, India, Int. J. Coal Geol., 42, 315-356, 2000.

Srivastava, J. and Prasad, V.: Effect of global warming on diversity pattern in Nypa mangroves across Paleocene-Eocene transition in the paleo-equatorial region of the Indian sub-continent, Palaeogeogr. Palaeocl., 429, 1-12, 2015.

Tewari, V. C., Kumar, K., Lokho, K., and Siddaiah, N. S.: Lakadong limestone: Paleocene-Eocene boundary carbonate sedimentation in Meghalaya, northeastern India, Curr. Sci. India, 98, 88-95, 2010 . 
Toumarkine, M.: Une nouvellee espèce d 'Orthophragmine de l'Eocene Marin du Mont-Cayla (Aude): Discocyclina neumannae, Rev. de Micropaléontologie, 10, 209-214, 1967.

Valet, G.: Approche paléoécologique du monde des Dasycladales a partir de l'écologie des formes actuelles, B. Cent. Rech. Expl., 3/2, 859-866, 1979.

Wan, X.: Palaeocene larger foraminifera from southern Tibet, Rev. Esp. Micropal., 23, 7-28, 1991.

Wan, X., Wang, X., and Jansa, L. F.: Biostratigraphy of a PaleoceneEocene Foreland Basin boundary in southern Tibet, Geosci. Front., 1, 69-79, 2010.

Warwick, P. D., Johnson, E. A., and Khan, I. H.: Collision-induced tectonism along the northwest margin of the Indian subcontinent as recorded in the Upper Paleocene to Middle Eocene strata of central Pakistan (Kirthar and Sulaiman Ranges), Palaeogeogr. Palaeocl., 142, 201-216, 1998.

Willems, H., Zhou, Z., Zhang, B., and Gräfe, K. U.: Stratigraphy of the Upper Cretaceous and Lower Tertiary strata in the Tethyan Himalayas of Tibet (Tingri area, China), Geol. Rundsch, 85, 723-754, 1996.

Wilson, G. E. and Metre, W. B.: Assam and Arakan, in: World's Oil Field: The Eastern Hemisphere: The Science of Petroleum, edited by: Illing, V. C., 6, 119-123, Oxford University Press, London, 1953.
Yin, A., Dubey, C. S., Webb, A. A. G., Kelty, T. K., Grove, M., Gehrels, G. E., and Burgess, W. P.: Geological correlation of the Himalayan orogen and Indian craton: Part 1. Structural geology, $\mathrm{U}-\mathrm{Pb}$ zircon geochronology, and tectonic evolution of the Shillong Plateau and neighboring regions in NE India, Geol. Soc. Am. Bull., 122, 336-359, 2010.

Zakrevskaya, E. Y.: The late Paleocene species Discocyclina seunesi Douvillé in Eastern Crimea, in: Paleontological investigations in Ukraine. Sbornik nauchnyh trudov IGN NAN Ukrainy, edited by: Gozhyk, P. F., Kiev, 228-232, 2007 (in Russian with English abstract).

Zernetskii, B. F.: First Discocyclina found in the Paleocene of Crimea, Materials on Cenozoic Paleontology of the Ukraine, Naukova Dumka, Kiev, 55-59, 1977.

Zhang, Q., Willems, H., Ding, L., Grafe K., and Appel, E.: Initial India-Asia collision and foreland basin evolution in the Tethyan Himalaya of Tibet: Evidence from stratigraphy and paleontology, J. Geol., 120, 175-189, 2012.

Zhang, Q., Willems, H., and Ding, L.: Evolution of the PaleoceneEarly Eocene larger benthic foraminifera in the Tethyan Himalaya of Tibet, China, Int. J. Earth Sci., 102, 1427-1445, 2013. 